\title{
Multi-layered global gene regulation in mouse embryonic stem cells
}

\author{
Samuel Beck $\cdot$ Bum-Kyu Lee $\cdot$ Jonghwan Kim
}

Received: 29 July 2014/Revised: 9 September 2014/ Accepted: 11 September 2014/Published online: 17 September 2014

(C) The Author(s) 2014. This article is published with open access at Springerlink.com

\begin{abstract}
Embryonic stem (ES) cells derived from the inner cell mass of developing embryos have tremendous potential in regenerative medicine due to their unique properties: ES cells can be maintained for a prolonged time without changes in their cellular characteristics in vitro (self-renewal), while sustaining the capacity to give rise to all cell types of adult organisms (pluripotency). In addition to the development of protocols to manipulate ES cells for therapeutic applications, understanding how such unique properties are maintained has been one of the key questions in stem cell research. During the past decade, advances in high-throughput technologies have enabled us to systematically monitor multiple layers of gene regulatory mechanisms in ES cells. In this review, we briefly summarize recent findings on global gene regulatory modes in ES cells, mainly focusing on the regulatory factors responsible for transcriptional and epigenetic regulations as well as their modular regulatory patterns throughout the genome.
\end{abstract}

Keywords Transcriptional regulation .

Cis-regulatory element · Enhancer · Promoter .

Core pluripotency factors .

MYC class DNA binding protein (DBPs) ·

Polycomb repressive complex (PRC) - Co-occupancy ·

Epigenetic regulation - Histone modification ·

Histone modifiers · DNA methylation .

S. Beck and B.-K. Lee contributed equally to this work.

S. Beck · B.-K. Lee $\cdot$ J. Kim $(\bowtie)$

Department of Molecular Biosciences, Institute for Cellular and

Molecular Biology, Center for Systems and Synthetic Biology,

The University of Texas at Austin, Austin, TX 78712, USA

e-mail: jonghwankim@mail.utexas.edu
Chromatin remodeler · High-order chromosomal structure ·

Long-range chromosomal interaction .

Chromosomal territory .

Modular transcriptional regulation .

Protein-protein interaction (PPI) .

Protein-DNA interaction (PDI)

$\begin{array}{ll}\text { Abbreviations } & \\ \text { ES cell } & \text { Embryonic stem cell } \\ \text { ICM } & \text { Inner cell mass } \\ \text { DBP } & \text { DNA-binding proteins } \\ \text { TF } & \text { Transcription factor } \\ \text { TE } & \text { Trophectoderm } \\ \text { LIF } & \text { Leukemia inhibitory factor } \\ \text { ChIP } & \text { Chromatin immunoprecipitation } \\ \text { PET } & \text { Paired-end tag } \\ \text { ChIP-seq } & \text { Chromatin immunoprecipitation followed } \\ & \text { by massive-parallel sequencing } \\ \text { PPI } & \text { Protein-protein interaction } \\ \text { PDI } & \text { Protein-DNA interaction } \\ \text { NODE } & \text { Nanog and Oct4-associated deacetylase } \\ \text { NuA4 } & \text { Nucleosome acetyltransferase of H4 } \\ \text { CGI } & \text { CpG island } \\ \text { DNMT } & \text { DNA methyltransferase } \\ \text { Mbd } & \text { Methyl-binding domain containing protein } \\ \text { NuRD } & \text { Nucleosome remodeling deacetylase } \\ \text { DKO } & \text { Double knockout } \\ \text { H3K36me3 } & \text { Histone H3 lysine 36 trimethylation } \\ \text { H3K4me1 } & \text { Histone H3 lysine 4 monomethylation } \\ \text { H3K4me3 } & \text { Histone H3 lysine 4 trimethylation } \\ \text { H3K27me3 } & \text { Histone H3 lysine 27 trimethylation } \\ \text { H3K27ac } & \text { Histone H3 lysine 27 acetylation } \\ \text { H2AK119ub } & \text { Histone H2A lysine 119 ubiquitination } \\ \text { EB } & \text { Embryoid body } \\ & \end{array}$




$\begin{array}{ll}\text { CHD } & \text { Chromodomain helicase DNA-binding } \\ \text { FISH } & \text { Fluorescence in situ hybridization } \\ \text { 3C } & \begin{array}{l}\text { Chromosome conformation capture } \\ \text { Circular chromosome conformation capture }\end{array} \\ \text { 4C } & \begin{array}{l}\text { Carbon-copy chromosome conformation } \\ \text { 5C }\end{array} \\ \text { chipture } \\ \text { Chromatin interaction analysis by paired- } \\ \text { PolII } & \begin{array}{l}\text { end tag sequencing } \\ \text { RNA polymerase II }\end{array}\end{array}$

\section{Introduction}

Embryonic stem (ES) cells are in vitro cultural counterparts of the inner cell mass (ICM, mouse) [1] or epiblast (human) [2] of developing embryos. These cells self-renew for a prolonged time in vitro while keeping their potential to generate all three germ layers (pluripotency) [3]. Due to these unique characteristics which are not observed in their in vivo counterparts, ES cells have attracted tremendous attention as useful tools for studying early mammalian development, making genetically-modified mouse models to unravel gene functions [4], and nurturing future therapeutic applications in regenerative medicine.

During the early era of mouse ES cell studies, establishments of ES cells were limitedly successful in only few mouse strains [3, 5]. Therefore, ES cells were often regarded as cultural artifacts until ES cells from other species/strains were later reported [3]. However, the limitations in deriving ES cells due to the initial strain dependency forced various studies to be performed on almost identical genetic backgrounds and culture conditions, allowing diverse data sets from independent experiments to be easily integrated for systematic analyses. Except for a few human cell lines extensively tested by the ENCODE project [6, 7], mouse ES cells are the most widely studied mammalian model system.

Over the last decade, understanding the underlying regulatory mechanisms enabling the unique characteristics of ES cells has been one of the major goals in the field of stem cells and developmental biology [3,8]. Besides the uniqueness of ES cells, accumulated knowledge of transcriptional regulations in ES cells significantly advanced our view of mammalian gene regulation. In particular, recently developed high-throughput methodologies, such as massive-parallel sequencing [9], enabled researchers to perform unbiased mappings of chromosomal targets of many transcription factors (TFs), DNA-binding proteins (DBPs), and epigenetic regulators, as well as epigenetic modifications including DNA and histone modifications. These efforts tremendously expanded our understanding of the regulatory mechanisms of global gene expression programs in ES cells where various regulatory entities are sophisticatedly interconnected to sustain the unique identities of ES cells.

In this review, we provide an overview of recent advances in understanding global gene regulatory mechanisms in mouse ES cells. We summarize key regulatory factors and their roles in transcriptional and epigenetic regulations. Another focus is on global gene regulations mediated by long-range interactions among multiple chromatin domains in ES cells. We also discuss ES cellspecific modular regulations where functionally separable sub-networks are tightly intertwined to maintain selfrenewal and pluripotency of mouse ES cells.

\section{Transcriptional regulation in es cells}

As one of the key regulatory mechanisms determining cellular characteristics, transcriptional regulation is mediated by multiple components including cis-regulatory elements (promoters, enhancers, and insulators) and transacting factors (sequence-specific TFs, general TFs, coactivators [10], co-repressors, mediators [11], chromatin modifiers, and chromatin remodelers [12, 13]). The importance of transcriptional regulation was recently highlighted by master TFs-mediated cell fate changes, such as somatic cell reprogramming [14] and trans-differentiation [15-19].

Core pluripotency TFs in ES cells

In ES cells, Oct4, Sox 2 and Nanog have been traditionally considered the core pluripotency TFs. The core TFs are exclusively expressed in early embryos and play critical roles in maintaining ES cell identity by governing the ES cell-specific gene expression program [20]. They were initially identified in loss-of-function studies, and an individual disruption of Oct4 [21], Sox2 [22] or Nanog [23] abolished early embryogenesis due to the failures of forming intact ICM, where mouse ES cells are derived, indicating their central roles in establishing and maintaining the pluripotency of ES cells. Proper levels of the core TFs in ES cells are important for both maintaining pluripotency and suppressing differentiation. Niwa et al. [24, 25] showed that approximately twofold induction of Oct4 in mouse ES cells prompts mesodermal and endodermal differentiation, while $50 \%$ reduction of Oct 4 results in differentiation toward a trophectoderm (TE) lineage by inducing $\mathrm{Cdx} 2$ and Eomes. Moreover, a recent study by Radzisheuskaya et al. [26] shows the reduced level of Oct4 in ES cells results in the failure of normal differentiation into embryonic lineages, while restoration of Oct4 rescues the differentiation capability. Consistently, Oct $4^{+/-}$ES 
cells can maintain stabilized pluripotency state accompanying with increased Oct4 occupancy across the genome, but shows compromised differentiation due to the delay in initial exit from the ESC state [27]. These results indicate that the level of Oct4 in wild-type ES cells is necessary for proper differentiation into all embryonic lineages. Similarly, the knockdown of Sox 2 in ES cells leads to primarily TE differentiation [28, 29], whereas ectopic expression of Sox 2 induces multiple lineages [30]. The similar phenotypic consequences upon perturbations of Oct4 or Sox2 imply a functional linkage between these two master TFs. Consistently, Oct 4 and Sox 2 form a heterodimer and synergistically activate their pluripotency-related target genes, including Nanog [31] and Fgf4 [32]. Unlike Oct4 and Sox2, an elevated level of Nanog was sufficient to maintain mouse ES cells without leukemia inhibitory factor (LIF), and Nanog-deficient ICM was prone to differentiate into parietal endoderm-like cells and fail to form an intact epiblast [23, 33]. However, further study performed by Chambers et al. [34] showed that, although they are prone to differentiate, Nanog null ES cells can self-renew infinitely in vitro, colonize embryonic germ layers, and contribute to the somatic lineages of fetal and adult chimaeras. Further studies suggested that pluripotencyrelated TFs are not only critical in ES cell maintenance but also function as lineage-specifying factors [35-37].

Initial efforts to understand global target gene regulation by the core TFs were made using human [20] and mouse [38, 39] ES cells by combining chromatin immunoprecipitation (ChIP) and microarray (ChIP-chip) or paired-end tag sequencing (ChIP-PET), revealing that the core TFs share a substantial number of common target genes including core TFs themselves [20]. These core pluripotency TFs-mediated auto-regulatory and feed-forward regulatory mechanisms suggested that the core TFs form a tight regulatory circuit to maintain ES cells. More recently, ChIP analyses followed by massive-parallel sequencing (ChIP-seq) uncovered that the core TFs co-occupy mainly distal enhancer regions rather than promoters of target genes [40] to form pluripotency-specific enhanceosomes in mouse ES cells [41-43].

\section{Extended core regulatory network in ES cells}

To gain more insights into the detailed action mechanisms of the core pluripotency TFs, pull-downs of protein complexes followed by mass spectrometry analyses were performed, and various interaction partner proteins of the core TFs were identified [44-49]. Orkin and colleagues [44] conducted a pioneer work to define a Nanog-centered protein-protein interaction (PPI) network and found multiple previously unknown Nanog-associated proteins, including Nacc1 (Nac1), Zfp281, Dax1, Sall4, and Rif1.
From subsequent pull-downs of newly-identified Nanogassociated proteins they constructed an extended Nanogcentered PPI network [44]. Interestingly, depletion of $\mathrm{Na}$ nog-associated factors in ES cells often showed the loss of pluripotency, suggesting that many Nanog-associated TFs may play critical roles in the maintenance of ES cells. A more recent study has newly identified eight additional Nanog-interacting partners, including Tet (10-11 translocation) family proteins, which synergistically enhance somatic cell reprogramming with Nanog [50]. Oct4-centered PPI network was also defined by multiple independent research groups; van den Berg et al. [46] showed that Oct4 is physically associated with 166 proteins, including TFs (Sall4, Tcfcp211, Dax1, and Esrrb) and chromatin modifiers (SWI/SNF and NuRD complexes) that are implicated in the self-renewal of ES cells. Depletion of Oct4 decreased the chromosomal target occupancy of Oct4-associated factors, indicating that Oct4 recruits its associated factors and cooperatively regulates their common targets. Another pull-down study of Oct4 by Pardo et al. [47] also revealed that Oct4 interacts with a wide range of TFs and epigenetic regulators. The mutations of Oct4-interacting partners often lead to the early lethality of developing embryos, indicating that Oct4-associated factors also exert critical roles in early embryogenesis. Although there was an apparent discrepancy between Oct4centered interactomes defined by these two independent groups, most recent mapping of Oct4 interaction partners by Ding et al. [48] identified larger size ( $\sim 198$ proteins) of high-confident Oct4-interactome with significant overlap with both of two previous studies [46, 47]. All these elements indicate that surprisingly many factors are involved in the regulation of ES cells in addition to the three core pluripotency TFs.

In addition to the PPI studies, an extended core TFcentered protein-DNA interaction (PDI) network was constructed using a ChIP-based method. Global target mapping of four somatic cell reprogramming factors (Oct4, Sox2, Klf4, and cMyc) [14] and some Nanog-associated TFs (Nanog, Dax1, Rex1, Zfp281, and Nacc1) [44] revealed that target genes bound by few factors tested are in general inactive, whereas common targets of many TFs are mostly active in ES cells [39]. The results suggest that there might be a differential gene regulatory mode relying on target co-occupancy of regulatory TFs. This observation also raises the question of how pluripotency factors discriminately activate or repress their target genes. One possible explanation is that multiple ES cell core TFs and their associated factors form enhanceosomes by co-occupying enhancers to promote target gene activation [40], while Oct4 and Nanog also form a distinctive repressive complex such as NODE (Nanog and Oct4-associated deacetylase), containing HDAC1/2 (histone deacetylases 
1/2) and Mta1/2 [45]. Induced expression of developmentrelated genes upon knockdown of the NODE complex subunit supported the idea that the NODE is responsible for the repression of lineage-specific marker genes in ES cells [45].

\section{Modular action of various TFs}

While unbiased mapping of targets of various TFs in ES cells disclosed their cooperative actions on common target gene regulations [20, 39, 40, 51], differential target occupancy patterns were observed between the targets of the core TFs and targets of cMyc $[40,51]$. The results indicated that TFs in ES cells can be divided into multiple distinct classes based on their target occupancy patterns. Recent analysis of the chromosomal targets of many active TFs in ES cells defined three functionally separable TF classes (Core, MYC and PRC; Table 1; Fig. 1a) [51]. The core pluripotency TFs, Oct4, Sox2 and Nanog, as well as other TFs, such as Smad1, Stat3, Nacc1, Dax1, and Zfp281, form the Core class TFs, and mainly co-occupy distal regulatory elements of mouse ES cells. On the other hand, cMyc, its binding partner proteins (Max, Tip60 and Dmap1), and other TFs sharing their targets with cMyc (Zfx, Cnot3, E2F1, and E2F4) form the MYC class and cooccupy mainly promoter elements of highly active genes in ES cells. The PRC class is composed of factors in polycomb repressive complexes 1 and 2 (PRC1 and PRC2, respectively), and occupies promoters of inactive genes, including lineage-specific regulators in ES cells. In the pluripotent state of ES cells, targets of the Core and MYC classes are highly active while targets of the PRC class are inactive [51]. Upon differentiation, targets of the Core and MYC classes are suppressed whereas targets of the PRC class are induced. Interestingly, target gene activities of the Core and MYC classes were opposite in partially reprogrammed cells [51], suggesting that each class of TFs may form a functionally separable regulatory subnetwork.

The core class TFs largely co-occupy distal enhancer elements of pluripotency-related genes with a previously known enhancer binding protein p300, a histone acetyltransferase [52], and form ES cell-specific enhanceosomes [40] to promote communication between enhancers and promoters via protein-mediated long-range interactions (Fig. 1b). Accordingly, Young and colleagues [53] reported that mediator proteins such as Med1 and Med12 share common targets with multiple core TFs. With extremely strong mediator occupancy signals, they further defined 'super-enhancers' spanning large domains of chromatin [54]. Their works additionally suggested that the context-dependent conformation of superenhancers bound by tissue-specific master TFs and mediators primarily determine the cell-type specific gene expression program. Interestingly, most recent study of Oct4 and Sox2 using single molecule imaging analyses in ES cells has revealed that Sox 2 binds first to target enhancers followed by the recruitment of Oct4 [55], suggesting that the core TFs assemble enhanceosomes in a hierarchical order. Notably, the Core class includes downstream effectors in signaling pathways, such as Smad1 and Stat3 [40], further supporting the notion that enhancers function as integration hubs of external signaling [56].

Unlike the Core class, ChIP-seq analyses revealed that the MYC and PRC classes preferentially occupy the proximal promoters of their target genes [51, 57]. Given that cMyc interacts with multiple proteins, including a NuA4 (nucleosome acetyltransferase of H4) complex in ES cells, and cooperatively regulates a common set of target genes, how the factors composing the NuA4 complex influence the pluripotent state of ES cells will be of great interest. Recently, two independent research groups reported that an elevated level of cMyc amplifies the expression of its already existing target genes instead of de novo activation of additional target genes [58, 59], suggesting that cMyc functions as a universal nonlinear amplifier for all active genes rather than a binary on-off switching factor. In agreement with this observation, Rahl et al. [60] showed that cMyc plays a key role in releasing paused RNA polymerase II (PolII) via its interaction with positive transcription elongation factor $\mathrm{b}(\mathrm{P}-\mathrm{TEFb})$ rather than recruiting PolII at its target genes. Although all these studies support that cMyc globally functions as a transcriptional activator, it also can, with Miz1 and/or other corepressor proteins such as Hdac1, suppress the expression of differentiation-related genes, including Hox cluster genes in human ES cells [61-64]. Future studies will be required to determine the mechanistic roles of $\mathrm{cMyc}$ as a repressor and its global contribution to promote the pluripotent state of ES cells.

Mapping unbiased targets of TFs is critical for understanding the roles of specific TFs. However, even with various individual and group efforts, less than $10 \%$ of DBPs within the genome have been subjected to ChIP-seq study in mammalian cells [7]. Since the majority of factors so far tested in ES cells belong to only a few classes, one obvious question is whether there are TFs forming unique subnetworks other than the three classes so far reported in ES cells [51]. The lack of ChIP-grade antibodies for a broad range of TFs has been an obstacle in mapping TF occupancies even with multiple systematic efforts to catalog ChIP-grade antibodies [65-67]. Alternative attempts, such as tagging TFs, have been tried to circumvent current limitations and to increase throughput [39, 68-70]. Considering the complexity of the global transcriptional regulation in which hundreds of DBPs are tightly interconnected with numerous cis-regulatory elements, further systematic studies of all active TFs in ES cells, possibly 


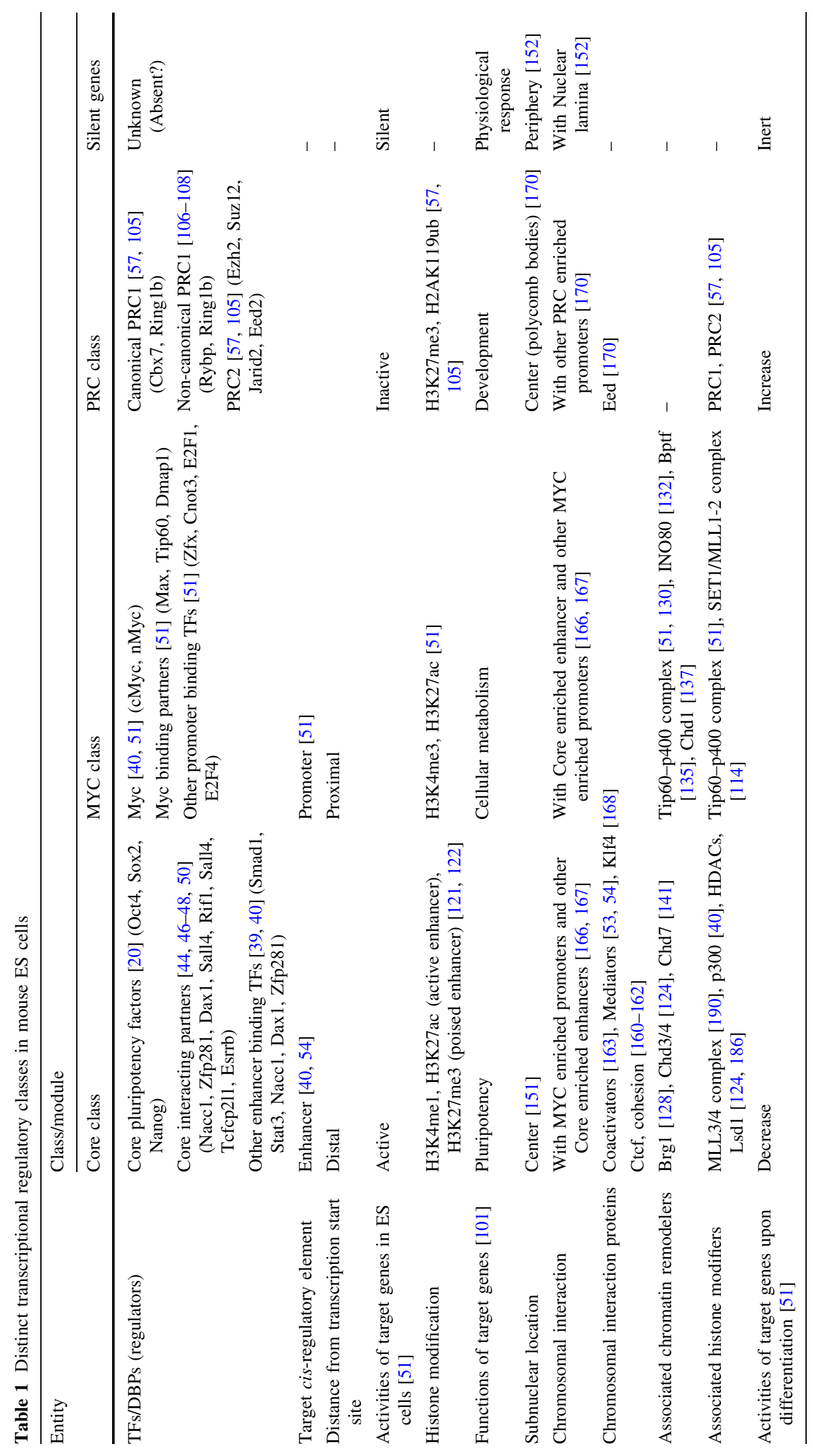


a

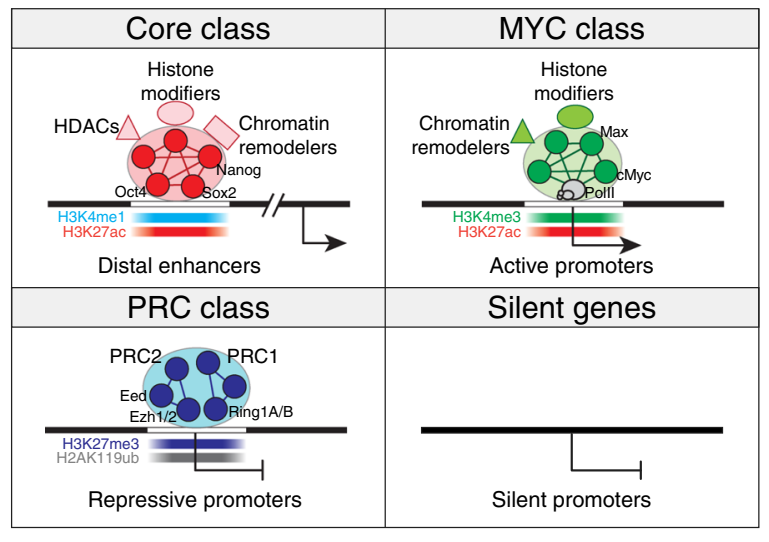

b

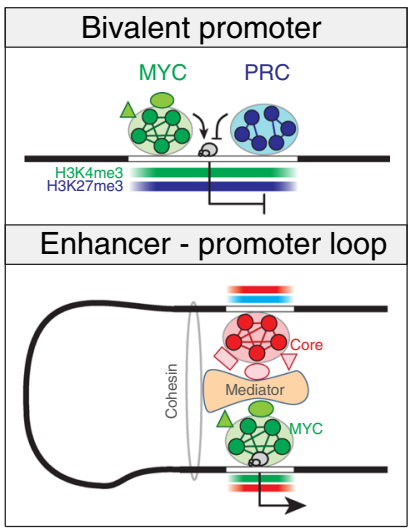

Methylated DNA Unmethylated DNA

C

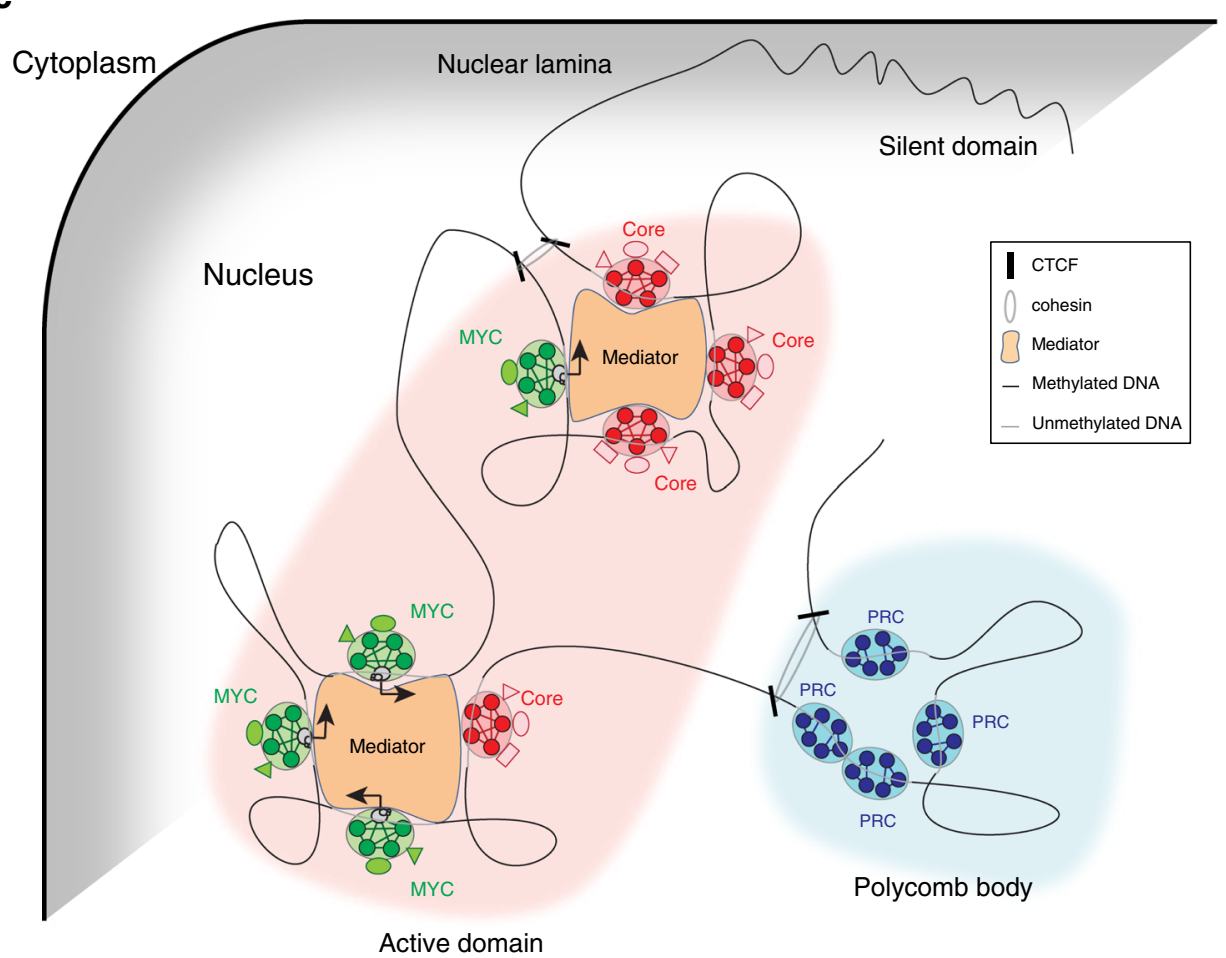

Fig. 1 Schematic representation of global gene regulatory modes in ES cells. a Transcriptional and epigenetic regulatory classes defined in ES cells. Recent studies of mapping targets of TFs and histonemodifying enzymes as well as histone modification signatures revealed that tested factors belong to mainly three classes based on their target co-occupancy (Core, MYC and PRC classes) [51]. As depicted, each class is associated with distinct TFs/DBPs, cisregulatory elements and histone modification marks. Notably, core pluripotency factors including Oct4 and Nanog belong to the Core class and occupy distal enhancer elements with enhancer specific histone modification marks (H3K4me1 and H3K27ac). Both MYC and PRC classes occupy proximal promoters, but show opposite target gene activities with unique histone modification marks (MYC class: H3K4me3 and H3K27ac; PRC class: H3K27me3 and H2AK119ub). Regulation of silent genes under the control of methylated promoters has not been well-understood in ES cells. Detailed factors, histone marks and other information involved in each regulatory class are summarized in Table 1. b Interactions between regulatory classes in ES cells. Proximal promoters of development or lineage specification-related genes that are mainly repressed in ES cells harbor bivalent histone marks (H3K4me3 and H3K27me3), and are associated with both MYC and PRC classes (upper panel). Distal enhancer elements occupied by the Core class factors interact with the MYC class-bound proximal promoters via a long-range chromosomal looping. Interactions between two classes are facilitated by mediator and cohesion complex (lower panel). c Spatial compartmentalization of chromosomal domains with regulatory classes. Active chromatin domains formed in the center of nucleus show tight interconnection between the Core and MYC classes via long-range chromosomal interactions. Genes repressed by the PRC class are co-localized and form nuclear sub-compartments called polycomb bodies. The repressive polycomb bodies are distinct from the nuclear lamina-associated silent domains anchoring at the nuclear periphery. Ctcf and cohesion demarcate chromatin domains 
with more advanced technologies, will be necessary to gain more comprehensive insights into the pluripotency-specific global transcriptional regulatory mechanisms in ES cells.

\section{Epigenetic regulation in ES cells}

In addition to transcriptional regulation, structural alterations of chromatin by epigenetic regulations including covalent modifications of DNA and histone tails, as well as alterations of nucleosome positions, render a favorable or unfavorable environment for TFs to interact with cis-regulatory elements of the genome, and eventually modulate a specific gene expression program. Together with TFs, elaborate and dynamic interplay among various epigenetic regulators play pivotal roles in maintaining the pluripotent state of ES cells as well as in determining proper cell fates during development.

The roles of DNA methylation in pluripotency of ES cells

The first layer of epigenetic regulation is DNA methylation, which primarily occurs at the cytosine of a $\mathrm{CpG}$ dinucleotide, producing 5-methylcytosine $(5 \mathrm{mC})$. In mammals, approximately, $70-80 \%$ of total $\mathrm{CpG}$ sequences in their genomes are methylated [71], while some cisregulatory regions, such as active enhancers or promoters are hypomethylated in a context-dependent manner [72]. Another type of DNA elements called 'CpG islands' (CGI), where multiple $\mathrm{CpG}$ dinucleotides are clustered and stretched near promoters [71], show mostly constant hypomethylation regardless of the tissue types or developmental stages [73, 74]. Among three well-conserved DNA methyltransferases (DNMTs; Dnmt1, Dnmt3a and Dnmt3b), Dnmt3a and Dnmt3b are responsible for de novo methylation during early embryogenesis [75]. On the other hand, Dnmt1 maintains genomic methylation during cell divisions. Deletion of both Dnmt3a and Dnmt3b blocks de novo methylation in ES cells, resulting in developmental abnormalities [76]. Similarly, homozygous deletion of Dnmt1 leads to delayed development followed by early embryonic lethality [77]. Notably, Dnmt1-null ES cells are capable of self-renewing in vitro [77], but die during differentiation due to increased apoptosis [78]. Overexpression of Dnmt1 also results in embryonic lethality due to the loss of imprinting caused by global hypermethylation of genome [79].

Although methylated DNA is generally considered a signature for gene silencing, some studies suggested that de novo methylation does not induce silencing of active promoters [80]. Therefore, the precise mechanisms involved in DNA methylation-mediated gene silencing still remain to be determined. One plausible model is that DNA methylation passively hampers the binding of TFs as most TFs preferentially bind to the regions lacking DNA methylation [81]. For example, the promoters of Oct4 and Nanog are hypomethylated in ES cells; however, $\mathrm{CpG}$ dinucleotides in those promoters become hypermethylated along with complete silencing of their expressions upon differentiation [82, 83]. Another model involves methyl-binding domain containing proteins (Mbds), which can recognize methylated DNAs and further interact with other repressor complex proteins [84]. Nucleosome-remodeling deacetylase (NuRD) complex, a well-known repressor complex comprising HDAC1, HDAC2, Mi-2 $\alpha / \beta$ (also known as Chd3/Chd4), RbA and Mta [84-87], binds to its target through Mbd proteins that can recognize methylated DNA [84].

Recently, important roles of Tet proteins (Tet1, Tet2 and Tet3), which can convert $5 \mathrm{mC}$ to various demethylated forms of DNA, such as 5-hydroxymethylcytosine $(5 \mathrm{hmC})$, 5-formylcytocine (5fC) and 5-carboxylcytosine (5caC), have been illuminated in ES cells [88, 89]. In particular, Tet1 sustains the level of Nanog in ES cells by maintaining consistent demethylation of Nanog promoters in ES cells [90]. Tet1/Tet2 proteins also physically interact with $\mathrm{Na}$ nog and facilitate somatic cell reprogramming by establishing naïve pluripotency through their catalytic activity [50]. Moreover, Tet1 replaces Oct4 during somatic cell reprogramming via reactivation of Oct4 by demethylation of the Oct4 promoter [91]. Genome-scale mapping studies also revealed that Tet 1 preferentially occupies CGI to prevent undesirable activity from DNMTs [92], contributing to the establishment of poised chromatin status, which is evidenced by the strong enrichment of $5 \mathrm{hmC}$, particularly in the proximal regions of transcription start sites harboring both active $(\mathrm{H} 3 \mathrm{~K} 4 \mathrm{me} 3)$ and repressive (H3K27me3) histone marks (see below) [93]. Conversely, other studies showed that Tet 1 single- or Tet1/Tet 2 doubleknockout (DKO) ES cells maintain pluripotency [94, 95]. Although a portion of Tet DKO embryos died before birth, apparently normal Tet mutant mice with slightly reduced levels of $5 \mathrm{hmC}$, as well as some aberrant methylation, raises speculation that Tet 3 may compensate for the loss of Tet 1 and Tet2. The individual Tet proteins need to be further characterized to clarify the roles of DNA methylation status in ES cells as well as during early developments.

Promoter-specific epigenetic regulations

Histone tails of eukaryotes are often covalently-modified with acetylation, methylation, phosphorylation, and ubiquitination, encompassing diverse information on local chromatin statuses, favorable for either activation or 
repression of related genes (histone code, [96]). Studies revealed that the chromatin architecture of ES cells is globally open, marked with abundant active histone signatures including $\mathrm{H} 3 \mathrm{~K} 4 \mathrm{me} 3$ and acetylation-enriched histones, and is transcriptionally hyperactive [97, 98]. In conjunction with these observations, the majority of promoters in ES cells harbor active histone marks, such as H3K4me3, H3K9ac and H3K14ac, accompanied by preloaded PolII [99]. These histone signatures are associated with transcription initiation, but only subsets of genes are transcribed into full-length mRNA with elongation histone marks (H3K36me3).

Interestingly, prior works showed that lineage-specific genes in ES cells harbor very distinct histone signatures called 'bivalent marks' (Fig. 1b) [100]. The repressed lineage-specific regulators have bivalent histones containing both active (H3K4me3) and repressive (H3K27me3) marks that are rapidly activated upon differentiation. Genes with bivalent marks or repressive mark (H3K27me3 only) in their promoters are functionally distinct from nonmarked genes (without $\mathrm{H} 3 \mathrm{~K} 4 \mathrm{me} 3 / \mathrm{H} 3 \mathrm{~K} 27 \mathrm{me} 3$ ) that are silent in ES cells (Table 1; Fig. 1a) [101, 102]. Intriguingly, promoters of the core TFs, such as Oct4, Sox 2 and Nanog, are switched from active (H3K4me3) to bivalent marks when ES cells undergo differentiation, revealing that histone modifications are not associated with a specific functional category of genes, but reflect the contextdependent activity of genes [101].

The two most well-known histone marks (H3K27me3 and $\mathrm{H} 3 \mathrm{~K} 4 \mathrm{me} 3$ ) are generally observed near the proximal promoters, and generated by PRC and Trithorax-group (TrxG) proteins, respectively [103, 104]. Polycomb complexes, PRC1 and PRC2, primarily suppress developmental regulators in ES cells [57, 105] by forming H2AK119ub and $\mathrm{H} 3 \mathrm{~K} 27 \mathrm{me} 3$, respectively. Recently, studies of CxxC domain containing proteins involved in the PRC-mediated repression revealed the sequential recruitment of PRCs to their repressive target genes. Briefly, CxxC containing $\mathrm{Kdm} 2 \mathrm{~b}$ occupies $\mathrm{CpG}$ promoters and recruits non-canonical PRC1 (Rybp-PRC1), priming a repressive histone mark (H2AK119ub), which in turn recruits PRC2, generating a H3K27me3 mark. Subsequently, canonical PRC1 (Cbx7$\mathrm{PRC} 1$ ) is recruited to further expand H2AK119ub mark [106-108]. Interestingly, deletion of subunits in PRC2 did not affect the self-renewal of ES cells [57, 105, 109, 110]. However, PRC2-depleted ES cells showed apparent defects in differentiation, suggesting the important roles of PRC in the proper differentiation of ES cells [110, 111].

The active histone mark H3K4me3 is catalyzed by TrxG group proteins such as Set1A/B or Mll1/2 (mixed lineage leukemia 1/2), forming a SET1/MLL complex [104, 112]. Wdr5, a core member of the SET1/MLL complex, physically interacts with Oct4, and its depletion impairs self- renewal of ES cells and somatic cell reprogramming [113]. In contrast, loss of Dpy-30, another subunit of the SET1/ MLL complex, abrogates pluripotency while maintaining self-renewal of ES cells [114]. Notably, the occupancy of TrxG group proteins is largely guided by MYC class TFs such as Max, as Max interacts with Wdr5 in ES cells [51] and in HeLa cells [115]. Mof, another MYC family protein, also plays an imperative role in sustaining ES cells by recruiting Wdr5 to active promoters via a physical interaction [116]. These observations provide strong evidence of the collaborative modular regulation of the MYC class TFs, TrxG proteins, and corresponding active histone signatures (Table 1$)$.

\section{Enhancer-specific epigenetic regulations}

Enhancers act over a long distance and enhance the activity of target gene promoters to govern the identity of specific cell types by connecting tissue-specific master TFs, mediators, and RNA PolII machinery [117]. The formation of enhancer-TFs complexes (enhanceosomes) is context-specific, as suggested in the interaction between core pluripotency TFs and ES cell-specific distal regulatory elements [40]. Recent genome-wide studies revealed that the global enhancer connectivity within the genome is extensively reorganized to change tissue-specific gene expression programs during differentiation [54, 118-120]. Although a conventional definition of enhancers was linked to their interaction with transcriptional co-activators [117], additional characteristics of enhancers, such as p300 occupancy and a prevalent $\mathrm{H} 3 \mathrm{~K} 4 \mathrm{me} 1$ mark, have been reported and have become widely used for the annotation of tissue-specific enhancer elements [56, 119, 121, 122]. Furthermore, more recent studies classified enhancers in ES cells into two groups (active and poised enhancers) depending on the combination of multiple histone marks $[119,121,122]$. Active enhancers are generally open with low nucleosome density and marked with both H3K4me1 and H3K27ac signatures with bindings of p300 and Brg1, a subunit of the SWI/SNF chromatin remodeling complex $[119,121,122]$. On the other hand, poised enhancers are functionally inert in self-renewing ES cells with H3K27me3 signatures, but rapidly acquire active enhancer signatures upon differentiation.

For successful differentiation of ES cells, active enhancers controlling ES cell-specific genes must be inactivated. Histone H3K4/K9 demethylase Lsd1 (also known as Kdm1a), the first mammalian histone demethylase identified [123], has been reported to localize at the active enhancers in ES cells and modulate the inactivation of ES cell-specific enhancers [124]. While Lsd1-depleted ES cells could self-renew normally in vitro, the cells showed defects in differentiation mainly due to the failure 
of histone demethylation at ES cell-specific enhancers. Other studies suggested that Lsd1 interacts with the NuRD complex, suggesting that other factors are also required for proper differentiation [124]. Consistently, ES cells lacking Mbd3, a subunit of NuRD complex, failed to silence the activity of pluripotency factors upon differentiation, and these cells self-renew even in the absence of LIF [125]. Interestingly, global target mapping of HDACs and NuRD complexes revealed that they are more enriched in the enhancers of active genes rather than repressed genes [124, 126], which is somewhat inconsistent with our general understanding of their repressive enzymatic functions. It is conceivable that HDACs may play a major role in attenuating the expression of active genes to balance their levels within an appropriate range, or they may prime active genes for future repression during differentiation.

Influence of chromatin remodeling on pluripotency of ES cells

ATP-dependent chromatin remodelers provide open or closed chromatin structures by rearranging nucleosome compositions or repositioning nucleosomes $[12,13]$. These local chromosomal changes, along with other histone and DNA modifying enzymes in either a conjunctive or sequential manner, affect the accessibility of transcriptional machineries onto cis-regulatory elements, and eventually determine local gene activity. ATP-dependent chromatin remodeling complexes can be divided into several groups, such as SWI/SNF, ISWI, and CHD, with different types of ATPase core subunits [13].

ES cells have a distinctive SWI/SNF complex so-called esBAF comprised of Baf155, Baf60A, Baf250a, and the ATP-dependent helicase Brg1 [127, 128]. Depletion of Baf250a resulted in defects, particularly in mesodermal lineage specifications upon differentiation of ES cells [129]. Brg1 co-localizes with the core TFs on pluripotencyspecific enhancers [128], implying its involvement in maintaining low nucleosomal density at enhancers. Another SWI/SNF complex, Tip60-p400, physically interacts and shares global targets with cMyc at active promoters harboring $\mathrm{H} 3 \mathrm{~K} 4 \mathrm{me} 3$ marks in mouse ES cells $[51,130]$. p400 has been known to replace H2A with histone variants such as $\mathrm{H} 2 \mathrm{~A} . \mathrm{Z}$ in the nucleosome of active promoters [131]. ES cells with depletion of Tip60 or p400 showed reduced proliferation, up-regulation of lineagespecific genes, defects in embryoid bodies (EB), and teratoma formations, indicating that Tip60-p400 is required for maintaining the identity of ES cells [130]. A recent study additionally revealed that INO80, another SWI/SNF chromatin-remodeling complex, is also critical for maintaining ES cell identity [132].
Mammalian ISWI ATP-dependent chromatin-remodeling complexes containing Snf2h or Snf2l ATPase facilitate the sliding of nucleosomes by disrupting the interactions between histone proteins and DNA [133]. The importance of Snf2h was shown by the embryonic lethality of Snf2hnull mice before implantation due to the defects in cell growth of the blastocyst stage embryo [134]. A study of another ISWI complex NURF (nucleosome remodeling factor) containing Snf2l and Bptf (bromodomain and PHD finger TF) revealed that Bptf is associated with $\mathrm{H} 3 \mathrm{~K} 4 \mathrm{me} 3$ marks [135]. Bptf-null ES cells showed deregulation of genes implicated in development of all three germ layers and genes particularly regulated by Smad, suggesting that Bptf links a Smad signaling pathway to the transcription of lineage-specific genes [136].

Chromodomain helicase DNA-binding (CHD) family chromatin remodelers also have been known to play critical roles in sustaining pluripotency. Chd1 recognizes H3K4me2/3 [137] and occupies the promoters of active genes where the MYC class TFs bind [51, 138]. Chd1deficient ES cells self-renew in vitro but are preferentially differentiated into neural lineages upon EB formation while showing defects in primitive endoderm differentiation [139]. Interestingly, these cells also showed accumulation of heterochromatin, suggesting that Chd1 plays direct roles in rendering open chromatin to prevent heterochromatin formation in ES cells [139]. A disruption of another CHD family, Chd7 in mouse embryos resulted in prenatal death due to the multiple tissue defects [140]. In ES cells, Chd7 co-localizes with the core factors on active enhancers [141] and plays a role as a molecular rheostat to maintain the level of ES cell-specific factors. As discussed earlier, Chd3/4, also known as Mi-2 $\alpha / \beta$ in NuRD complex, were also reported to occupy active enhancers in ES cells [124].

\section{Higher-order chromatin architecture}

So far, we discussed the factors responsible for the transcriptional and epigenetic regulations in ES cells and their functions occurring through local changes in chromatin structures of the genome. More recently, studies have revealed that chromatin structures are further organized into specific higher-order architectures depending on cell types and developmental stages [142]. A growing body of evidence supports that higher-order chromatin structures also play an imperative role as a new regulatory layer controlling stem cell characteristics. In this section, we summarize recent understandings of higherorder chromatin architectures mediated by long-range interactions. 
Unique and dynamic chromatin structures of ES cells

The chromatin structure of an ES cell is largely open with less heterochromatin composition, loosely compacted compared to the chromatin of differentiated cells, and transcriptionally hyperactive due to active chromatinremodeling enzymes and general TFs [97, 143, 144]. The chromatin plasticity of ES cells is believed to secure rapid genomic adaptation upon differentiation to promote lineage-specific gene expression programs [145, 146]. The recently developed $\mathrm{Hi}-\mathrm{C}$ assay [147], a powerful tool in identifying global higher-order chromatin interactions, suggested that chromatins are largely organized with distinct megabase-sized topological domains [148]. This is consistent with previous microscopic observations of subcellular gene locations showing that gene-enriched chromosomal domains are located in the center of the nucleus, while gene-depleted regions or centromeres are found in the nuclear periphery (Fig. 1c) [149, 150]. Chromosomes of human ES cells showed similar organization wherein pluripotency genes, such as Nanog and Oct4, are located closer to the center of the nucleus [151]. Upon differentiation, repressive histone modifications are elevated globally while pluripotency genes are relocated from the center of the nucleus to the nuclear lamina to become silenced [152]. These results suggest that the genomic structures of ES cells are not only established to provide a favorable environment for maintaining ES cell identity, but also experience reorganization to benefit specific lineage commitments during differentiation.

\section{Techniques for chromosomal conformation capturing}

Early studies of chromatin conformations relied on microscopic observation via DNA fluorescence in situ hybridization (FISH) for a limited number of genomic loci. Chambeyron et al. [153] showed that the extrusion of a Hoxb locus from its chromosomal territories coincides with its activation. This observation brought up the idea that chromosomal localization may affect gene activity. Thanks to the development of chromosome conformation capture (3C) technology, local chromatin structures and small-scale physical interactions between distant genomic regions have been studied in depth $[154,155]$. To identify multiple interacting regions of a given genomic locus, chromosome capture has been integrated with circularization (circular chromosome conformation capture: 4C) or other genomewide analysis tools, such as tiling array (4C-array or chromosome conformation capture-on-chip [156]) and high-throughput parallel sequencing (4C-seq [157]). Additional approaches were invented to capture chromosomal interactions within a cell as a whole (carbon-copy chromosome conformation capture: 5C [158], Hi-C [147]).
More recently, a new method was developed to study unbiased chromosomal interactions mediated by specific proteins (chromatin interaction analysis by paired-end tag sequencing: ChIA-PET, for the review of technological details, see [155]).

Long-range interaction mediated higher-order chromatin structures in ES cells

It has been shown that long-range interactions and higherorder chromatin structures are mediated by specific proteins [159] such as nuclear Ctcf/cohesin [160-162], p300/ Cbp [163], and mediators [164, 165], and these proteins link one chromosomal region to another via long-range looping. An integrative analysis using HI-C and Ctcf ChIPseq in human cells revealed that Ctcf is a major architect building chromosomal structures by mediating interactions both within a chromosome and between different chromosomes (Fig. 1c) [161]. ChIA-PET assays of Ctcf in mouse ES cells identified 1,480 cis- and 336 trans-acting chromatin interactions [160], and another study on Ctcfmediated loops unveiled that Ctcf partitions distinct chromatin compartments with different transcriptional and epigenetic statuses [162]. Ctcf loops also determine the boundaries of lamin-associated silent chromosomal regions and function as a barrier between silent and active regions [162].

Additionally, ChIA-PET assays of PolII disclosed interactions between multiple active promoters ( $\mathrm{P}-\mathrm{P}$ interactions) and pervasive interactions between promoters and enhancers (P-E interactions) [166, 167]. Notably, promoters of the core TFs (Oct4, Sox2, Nanog, and Klf4) are interconnected within close physical proximity in ES cells. However, in neural stem cells, Sox 2 gene is connected with Olig1 and Olig2 genes that play important roles in decision of neural cell fate, implying that gene relocation and replacement of interaction partners coincide with differentiation. On the other hand, regulatory elements of Oct4 gene lacking PolII-mediated chromatin interactions in somatic cells obtain intrachromosomal interactions during somatic cell reprogramming [166], highlighting critical roles of long-range looping-mediated chromatin structure changes in pluripotency-specific gene expression programs. Notably, unlike a prior assumption of proximitygoverned interactions between enhancers and promoters, this work revealed that approximately $75 \%$ of enhancers communicate with distal promoters rather than their nearest promoters.

Mediators are major culprits in linking promoters and enhancers as a complex with cohesin, bridging two different chromosomal regions by encircling them with cohesin rings [53]. Depletion of these proteins in ES cells results in overall collapse of ES cell-specific chromatin 
interactions and loss of a pluripotent state. Moreover, as discussed earlier, extremely high levels of mediator occupancy are associated with super-enhancers that regulate a global tissue-specific gene expression program, supporting the importance of long-range interactions mediated by mediators [54]. Other co-activators, such as p300 and Cbp, also mediate long-range looping at Nanog locus in ES cells by physical interaction with Nanog proteins, in turn activating other pluripotency genes [163].

The fact that pluripotency factors such as Oct4 and Nanog particularly bind to the enhancers of ES cell-specific genes suggested that pluripotency factors may also play important roles in organizing chromatin configurations. A recent $4 \mathrm{C}$-seq study has revealed that Klf4 proteins recruit cohesin onto the Oct4 enhancer before the activation of endogenous Oct4 during somatic cell reprogramming [168]. Similarly, depletion of Klf4 leads to differentiation of ES cells due to the disruption of Klf4-mediated longrange interactions between Oct4 enhancers and promoters, indicating that Klf4 also involves high-order chromatin architecture to induce pluripotency [168]. Another 4C-seq study of Nanog locus also emphasized the interactions between Nanog locus and other pluripotency-specific genes [169]. Importantly, Eed-mediated long-range looping at the PRC-mediated repressive regions also has been reported [170]. Particularly, genes repressed by PRC are co-localized together within distinct nuclear sub-compartments called polycomb bodies [171] that are different from previously known silent nuclear peripheries (Table 1; Fig. 1c) [170].

\section{Summary and future perspectives}

Interconnection of multiple regulatory mechanisms

Research in the past decade aided by modern systems biology tools have demonstrated that the global gene expression program in mouse ES cells is controlled by multiple layers of regulatory steps, such as transcriptional and epigenetic regulations. Emerging patterns of tightly interconnected regulatory pathways are more evident with recent demonstrations of long-range interactions among various cis- and trans-regulatory elements.

Epigenetic signatures generated by the recruitment and action of histone modifiers [52, 172, 173] and chromatin remodeling complexes [12, 87] are intertwined with transcriptional regulation mediated by sequence-specific and general TFs. De novo bindings of TFs to their target sites are affected by pre-formed local nucleosome density [174, 175], DNA methylation status [81], epigenetic modifications [172], and other preoccupied transcription factors [176]. Sequence information in cis-regulatory elements becomes functional only when they are occupied by regulatory factors with accompanying chromatin and epigenetic statuses. Now it is clear that these associations between epigenetic modifications and TF occupancies are collectively formed within separate chromosomal territories [148] with long-range interactions [166]. Table 1 summarizes interrelations between each transcriptional regulatory class so far known in ES cells and the entities of global gene regulation, including TFs, epigenetic regulators, epigenetic modifications, chromatin status, subcellular localizations, and so on. All these regulatory layers and regulators should be collectively considered as a whole, not as separate entities, for a more comprehensive understanding of pluripotency-specific gene expression program.

Implications of modular transcription and epigenetic regulations

Notably, analysis of accumulated TF or DBP occupancy data suggested that a group of TFs or regulators tend to share similar chromosomal targets as a functionally separable regulatory subunit as shown in mouse ES cells: the Core, MYC and PRC classes [51]. The co-occupancy mediated modular action of TFs seems to help transcriptional controls in diverse ways. First, the cooperation of multiple TFs within each class may secure the successful execution of gene regulation compared to the sole action of a single TF. Conversely, each TF within a subnetwork may have unique functions to make up a complete functionality, as Tcf3, a negative regulator of transcription, shares common targets with the core factors in ES cells and balances the levels of the core factors [177]. Second, more importantly, TFs or DBPs within a subnetwork are almost always associated with distinct histone-modifying enzymes and histone modification marks, as summarized in Table 1 and Fig. 1, suggesting that the gene expression programs in ES cells is achieved by the modular actions of both TFs and epigenetic regulators. This view is particularly imperative, as suggested in the works by Zaret and colleagues [176, 178-180]; pioneering factors recognize and occupy target sequences in an epigenetic status-independent manner at the beginning, and then recruit other TFs or epigenetic regulators, allowing changes in chromatin status, further interacting with other cis-regulatory elements to form higher-level chromatin interactions, in turn changing cellular characteristics [167, 179, 181]. Third, the modular actions of TFs and epigenetic regulators seem to ensure rapid and precise cellular responses in environmental changes, as shown in Lsd1 and Mi-2/NuRD cases [124]. As discussed above, these putative repressors are responsible for the removal of pluripotency-specific enhancers upon differentiation, implying their roles in rapid response to environmental changes. Last, the modular action of 
multiple factors also involves signal transduction pathways [40]. As most effectors of signaling pathways are TFs, their actions are dependent on the pre-formed modular regulatory network, such as enhanceosomes [40]. This also explains previous observations of context-specific responses of signaling pathways [182-184].

\section{Implication of chromosomal interactomes}

Recently attained knowledge on chromatin conformation in ES cells suggested important biological significances. Considering limited cellular resources, spatial segregation of active, repressive and silent regions may enable more efficient way of gene regulation [170]. In addition, as described above, chromosomal conformations not only constrain global gene expression, but also involve gene activity changes in response to environmental changes or differentiation cues [166, 185].

Moreover, results from the enhancer-promoter interactome studies disclosed that multiple enhancers interact not only with a single promoter, but frequently with multiple promoters to form clusters of multiple co-expressed genes $[166,167]$. More collective and high-ordered approaches to map global chromosomal interactomes will be required for the acquisition of more comprehensive views of global gene regulatory mechanisms.

\section{Future directions}

To our surprise, some of the newly-attained genome-wide data seemed somewhat inconsistent with our conventional understanding of the functions. For example, the genomic targets of some previously known repressor proteins such as Lsd1 [124, 186] and Hdac1 [126] are near the regulatory elements of active genes rather than the repressed genes in ES cells. Moreover, general approaches of mapping TF targets often do not show any strong correlation with the activity of the target genes upon perturbation of tested factors [187-189]. Therefore, to get better insights into the roles of TFs or epigenetic regulators, in addition to their enzymatic functions and context-dependent genome-wide occupancies, the interacting partners, target cis-elements and three-dimensional chromatin interactions should be considered together. Aligned with these comprehensive studies linking diverse aspects of gene regulations, conventional genetics studies aiming to understand the functions of each regulatory factor in early development or in vivo should also be continued.

Acknowledgments We thank Dr. Andrew J. Woo and Ms. Laurie Cannon for critical reading of the manuscript. J. K. is supported by awards R00GM088384 from the NIH/NIGMS and R1106 from the Cancer Prevention Research Institute of Texas (CPRIT) to J. K. J. K. is a CPRIT Scholar.
Open Access This article is distributed under the terms of the Creative Commons Attribution License which permits any use, distribution, and reproduction in any medium, provided the original author(s) and the source are credited.

\section{References}

1. Evans MJ, Kaufman MH (1981) Establishment in culture of pluripotential cells from mouse embryos. Nature 292(5819): 154-156

2. Thomson JA, Itskovitz-Eldor J, Shapiro SS, Waknitz MA, Swiergiel JJ, Marshall VS, Jones JM (1998) Embryonic stem cell lines derived from human blastocysts. Science 282(5391):1145-1147

3. Smith AG (2001) Embryo-derived stem cells: of mice and men. Annu Rev Cell Dev Biol 17(1):435-462

4. Chisaka O, Capecchi MR (1991) Regionally restricted developmental defects resulting from targeted disruption of the mouse homeobox gene hox-1.5. Nature 350(6318):473-479

5. Kawase E, Suemori H, Takahashi N, Okazaki K, Hashimoto K, Nakatsuji N (1994) Strain difference in establishment of mouse embryonic stem (ES) cell lines. Int J Dev Biol 38(2):385-390

6. ENCODE (2007) Identification and analysis of functional elements in $1 \%$ of the human genome by the ENCODE pilot project. Nature 447(7146):799-816

7. ENCODE (2012) An integrated encyclopedia of DNA elements in the human genome. Nature 489(7414):57-74

8. Young Richard A (2011) Control of the embryonic stem cell state. Cell 144(6):940-954

9. Johnson DS, Mortazavi A, Myers RM, Wold B (2007) Genomewide mapping of in vivo protein-DNA interactions. Science 316(5830):1497-1502

10. Naar AM, Lemon BD, Tjian R (2001) Transcriptional coactivator complexes. Annu Rev Biochem 70:475-501

11. Ansari S, Morse R (2013) Mechanisms of mediator complex action in transcriptional activation. Cell Mol Life Sci 70(15):2743-2756

12. Vignali M, Hassan AH, Neely KE, Workman JL (2000) ATPdependent chromatin-remodeling complexes. Mol Cell Biol 20(6):1899-1910

13. Narlikar GJ, Sundaramoorthy R, Owen-Hughes T (2013) Mechanisms and functions of ATP-dependent chromatinremodeling enzymes. Cell 154(3):490-503

14. Takahashi K, Yamanaka S (2006) Induction of pluripotent stem cells from mouse embryonic and adult fibroblast cultures by defined factors. Cell 126(4):663-676

15. Zhou Q, Brown J, Kanarek A, Rajagopal J, Melton DA (2008) In vivo reprogramming of adult pancreatic exocrine cells to beta-cells. Nature 455(7213):627-632

16. Vierbuchen T, Ostermeier A, Pang ZP, Kokubu Y, Sudhof TC, Wernig M (2010) Direct conversion of fibroblasts to functional neurons by defined factors. Nature 463(7284):1035-1041

17. Ieda M, Fu JD, Delgado-Olguin P, Vedantham V, Hayashi Y, Bruneau BG, Srivastava D (2010) Direct reprogramming of fibroblasts into functional cardiomyocytes by defined factors. Cell 142(3):375-386

18. Sekiya S, Suzuki A (2011) Direct conversion of mouse fibroblasts to hepatocyte-like cells by defined factors. Nature 475(7356):390-393

19. Ladewig J, Koch P, Brustle O (2013) Leveling Waddington: the emergence of direct programming and the loss of cell fate hierarchies. Nat Rev Mol Cell Biol 14(4):225-236

20. Boyer LA, Lee TI, Cole MF, Johnstone SE, Levine SS, Zucker JP, Guenther MG, Kumar RM, Murray HL, Jenner RG, Gifford 
DK, Melton DA, Jaenisch R, Young RA (2005) Core transcriptional regulatory circuitry in human embryonic stem cells. Cell 122(6):947-956

21. Nichols J, Zevnik B, Anastassiadis K, Niwa H, Klewe-Nebenius D, Chambers I, Scholer H, Smith A (1998) Formation of pluripotent stem cells in the mammalian embryo depends on the POU transcription factor Oct4. Cell 95(3):379-391

22. Avilion AA, Nicolis SK, Pevny LH, Perez L, Vivian N, LovellBadge R (2003) Multipotent cell lineages in early mouse development depend on SOX2 function. Genes Dev 17(1): 126-140

23. Mitsui K, Tokuzawa $\mathrm{Y}$, Itoh $\mathrm{H}$, Segawa K, Murakami M, Takahashi K, Maruyama M, Maeda M, Yamanaka S (2003) The homeoprotein Nanog is required for maintenance of pluripotency in mouse epiblast and ES cells. Cell 113(5):631-642

24. Niwa H, Miyazaki J, Smith AG (2000) Quantitative expression of Oct-3/4 defines differentiation, dedifferentiation or selfrenewal of ES cells. Nat Genet 24(4):372-376

25. Niwa H, Toyooka Y, Shimosato D, Strumpf D, Takahashi K, Yagi R, Rossant J (2005) Interaction between Oct3/4 and Cdx2 determines trophectoderm differentiation. Cell 123(5):917-929

26. Radzisheuskaya A, Le Bin Chia G, dos Santos RL, Theunissen TW, Castro LFC, Nichols J, Silva JCR (2013) A defined Oct4 level governs cell state transitions of pluripotency entry and differentiation into all embryonic lineages. Nat Cell Biol 15(6):579-590

27. Karwacki-Neisius V, Göke J, Osorno R, Halbritter F, Ng Jia H, Weiße Andrea Y, Wong Frederick CK, Gagliardi A, Mullin Nicholas P, Festuccia N, Colby D, Tomlinson Simon R, Ng H-H, Chambers I (2013) Reduced Oct4 expression directs a robust pluripotent state with distinct signaling activity and increased enhancer occupancy by Oct 4 and Nanog. Cell Stem Cell 12(5):531-545

28. Ivanova N, Dobrin R, Lu R, Kotenko I, Levorse J, DeCoste C, Schafer X, Lun Y, Lemischka IR (2006) Dissecting selfrenewal in stem cells with RNA interference. Nature 442(7102):533-538

29. Masui S, Nakatake Y, Toyooka Y, Shimosato D, Yagi R, Takahashi K, Okochi H, Okuda A, Matoba R, Sharov AA, Ko MSH, Niwa H (2007) Pluripotency governed by Sox2 via regulation of Oct $3 / 4$ expression in mouse embryonic stem cells. Nat Cell Biol 9(6):625-635

30. Kopp JL, Ormsbee BD, Desler M, Rizzino A (2008) Small increases in the level of Sox 2 trigger the differentiation of mouse embryonic stem cells. Stem Cells 26(4):903-911

31. Kuroda T, Tada M, Kubota H, Kimura H, Hatano SY, Suemori H, Nakatsuji N, Tada T (2005) Octamer and Sox elements are required for transcriptional cis regulation of Nanog gene expression. Mol Cell Biol 25(6):2475-2485

32. Yuan H, Corbi N, Basilico C, Dailey L (1995) Developmentalspecific activity of the FGF-4 enhancer requires the synergistic action of Sox 2 and Oct-3. Genes Dev 9(21):2635-2645

33. Chambers I, Colby D, Robertson M, Nichols J, Lee S, Tweedie S, Smith A (2003) Functional expression cloning of Nanog, a pluripotency sustaining factor in embryonic stem cells. Cell 113(5):643-655

34. Chambers I, Silva J, Colby D, Nichols J, Nijmeijer B, Robertson M, Vrana J, Jones K, Grotewold L, Smith A (2007) Nanog safeguards pluripotency and mediates germline development. Nature 450(7173):1230-1234

35. Wang Z, Oron E, Nelson B, Razis S, Ivanova N (2012) Distinct lineage specification roles for NANOG, OCT4, and SOX2 in human embryonic stem cells. Cell Stem Cell 10(4):440-454

36. Loh KM, Lim B (2011) A precarious balance: pluripotency factors as lineage specifiers. Cell Stem Cell 8(4):363-369
37. Thomson M, Liu SJ, Zou LN, Smith Z, Meissner A, Ramanathan S (2011) Pluripotency factors in embryonic stem cells regulate differentiation into germ layers. Cell 145(6):875-889

38. Loh Y-H, Wu Q, Chew J-L, Vega VB, Zhang W, Chen X, Bourque G, George J, Leong B, Liu J, Wong K-Y, Sung KW, Lee CWH, Zhao X-D, Chiu K-P, Lipovich L, Kuznetsov VA, Robson P, Stanton LW, Wei C-L, Ruan Y, Lim B, Ng H-H (2006) The Oct4 and Nanog transcription network regulates pluripotency in mouse embryonic stem cells. Nat Genet 38(4):431-440

39. Kim J, Chu J, Shen X, Wang J, Orkin SH (2008) An extended transcriptional network for pluripotency of embryonic stem cells. Cell 132(6):1049-1061

40. Chen X, Xu H, Yuan P, Fang F, Huss M, Vega VB, Wong E, Orlov YL, Zhang W, Jiang J, Loh YH, Yeo HC, Yeo ZX, Narang V, Govindarajan KR, Leong B, Shahab A, Ruan Y, Bourque G, Sung WK, Clarke ND, Wei CL, Ng HH (2008) Integration of external signaling pathways with the core transcriptional network in embryonic stem cells. Cell 133(6): $1106-1117$

41. Carey M (1998) The enhanceosome and transcriptional synergy. Cell 92(1):5-8

42. Panne D (2008) The enhanceosome. Curr Opin Struct Biol 18(2):236-242

43. Kim TK, Maniatis T (1997) The mechanism of transcriptional synergy of an in vitro assembled interferon- $\beta$ enhanceosome. Mol Cell 1(1):119-129

44. Wang J, Rao S, Chu J, Shen X, Levasseur DN, Theunissen TW, Orkin SH (2006) A protein interaction network for pluripotency of embryonic stem cells. Nature 444(7117):364-368

45. Liang J, Wan M, Zhang Y, Gu P, Xin H, Jung SY, Qin J, Wong J, Cooney AJ, Liu D, Songyang Z (2008) Nanog and Oct4 associate with unique transcriptional repression complexes in embryonic stem cells. Nat Cell Biol 10(6):731-739

46. van den Berg DL, Snoek T, Mullin NP, Yates A, Bezstarosti K, Demmers J, Chambers I, Poot RA (2010) An Oct4-centered protein interaction network in embryonic stem cells. Cell Stem Cell 6(4):369-381

47. Pardo M, Lang B, Yu L, Prosser H, Bradley A, Babu MM, Choudhary J (2010) An expanded Oct4 interaction network: implications for stem cell biology, development, and disease. Cell Stem Cell 6(4):382-395

48. Ding J, Xu H, Faiola F, Ma'ayan A, Wang J (2012) Oct4 links multiple epigenetic pathways to the pluripotency network. Cell Res 22(1):155-167

49. Gao Z, Cox JL, Gilmore JM, Ormsbee BD, Mallanna SK, Washburn MP, Rizzino A (2012) Determination of protein interactome of transcription factor Sox 2 in embryonic stem cells engineered for inducible expression of four reprogramming factors. J Biol Chem 287(14):11384-11397

50. Costa Y, Ding J, Theunissen TW, Faiola F, Hore TA, Shliaha PV, Fidalgo M, Saunders A, Lawrence M, Dietmann S, Das S, Levasseur DN, Li Z, Xu M, Reik W, Silva JC, Wang J (2013) NANOG-dependent function of TET1 and TET2 in establishment of pluripotency. Nature 495(7441):370-374

51. Kim J, Woo AJ, Chu J, Snow JW, Fujiwara Y, Kim CG, Cantor AB, Orkin SH (2010) A Myc network accounts for similarities between embryonic stem and cancer cell transcription programs. Cell 143(2):313-324

52. Ogryzko VV, Schiltz RL, Russanova V, Howard BH, Nakatani $\mathrm{Y}$ (1996) The transcriptional coactivators p300 and CBP are histone acetyltransferases. Cell 87(5):953-959

53. Kagey MH, Newman JJ, Bilodeau S, Zhan Y, Orlando DA, van Berkum NL, Ebmeier CC, Goossens J, Rahl PB, Levine SS, Taatjes DJ, Dekker J, Young RA (2010) Mediator and cohesin 
connect gene expression and chromatin architecture. Nature 467(7314):430-435

54. Whyte Warren A, Orlando David A, Hnisz D, Abraham Brian J, Lin Charles Y, Kagey Michael H, Rahl Peter B, Lee Tong I, Young Richard A (2013) Master transcription factors and mediator establish super-enhancers at key cell identity genes. Cell 153(2):307-319

55. Chen J, Zhang Z, Li L, Chen BC, Revyakin A, Hajj B, Legant W, Dahan M, Lionnet T, Betzig E, Tjian R, Liu Z (2014) Singlemolecule dynamics of enhanceosome assembly in embryonic stem cells. Cell 156(6):1274-1285

56. Buecker C, Wysocka J (2012) Enhancers as information integration hubs in development: lessons from genomics. Trends Genet 28(6):276-284

57. Boyer LA, Plath K, Zeitlinger J, Brambrink T, Medeiros LA, Lee TI, Levine SS, Wernig M, Tajonar A, Ray MK, Bell GW, Otte AP, Vidal M, Gifford DK, Young RA, Jaenisch R (2006) Polycomb complexes repress developmental regulators in murine embryonic stem cells. Nature 441(7091):349-353

58. Nie Z, Hu G, Wei G, Cui K, Yamane A, Resch W, Wang R, Green Douglas R, Tessarollo L, Casellas R, Zhao K, Levens D (2012) c-Myc is a universal amplifier of expressed genes in lymphocytes and embryonic stem cells. Cell 151(1):68-79

59. Lin CY, Loven J, Rahl PB, Paranal RM, Burge CB, Bradner JE, Lee TI, Young RA (2012) Transcriptional amplification in tumor cells with elevated c-Myc. Cell 151(1):56-67

60. Rahl PB, Lin CY, Seila AC, Flynn RA, McCuine S, Burge CB, Sharp PA, Young RA (2010) c-Myc regulates transcriptional pause release. Cell 141(3):432-445

61. Varlakhanova N, Cotterman R, Bradnam K, Korf I, Knoepfler P (2011) Myc and Miz-1 have coordinate genomic functions including targeting Hox genes in human embryonic stem cells. Epigenetics Chromatin 4(1):20

62. Staller P, Peukert K, Kiermaier A, Seoane J, Lukas J, Karsunky H, Moroy T, Bartek J, Massague J, Hanel F, Eilers M (2001) Repression of p15INK4b expression by Myc through association with Miz-1. Nat Cell Biol 3:392-399

63. Kime L, Wright S (2003) Mad4 is regulated by a transcriptional repressor complex that contains Miz-1 and c-Myc. Biochem J 370:291-298

64. Iraci N, Diolaiti D, Papa A, Porro A, Valli E, Gherardi S, Herold S, Eilers M, Bernardoni R, Valle GD, Perini G (2011) A SP1/ MIZ1/MYCN repression complex recruits HDAC1 at the TRKA and p75NTR promoters and affects neuroblastoma malignancy by inhibiting the cell response to NGF. Cancer Res 71(2): 404-412

65. Goens G, Rusu D, Bultot L, Goval J-J, Magdalena J (2009) Characterization and quality control of antibodies used in ChIP assays. In: Collas P (ed) Chromatin immunoprecipitation assays. Methods in molecular biology, vol 567. Humana Press, New York, pp 27-43

66. Wu AR, Kawahara TLA, Rapicavoli NA, Riggelen Jv, Shroff EH, Xu L, Felsher DW, Chang HY, Quake SR (2012) High throughput automated chromatin immunoprecipitation as a platform for drug screening and antibody validation. Lab Chip 12(12):2190-2198

67. Kidder BL, Hu G, Zhao K (2011) ChIP-Seq: technical considerations for obtaining high-quality data. Nat Immunol 12(10):918-922

68. Ma Z, Swigut T, Valouev A, Rada-Iglesias A, Wysocka J (2011) Sequence-specific regulator Prdm14 safeguards mouse ESCs from entering extraembryonic endoderm fates. Nat Struct Mol Biol 18(2):120-127

69. Kolodziej K, Pourfarzad F, de Boer E, Krpic S, Grosveld F, Strouboulis J (2009) Optimal use of tandem biotin and V5 tags in ChIP assays. BMC Mol Biol 10(1):6
70. Mazzoni EO, Mahony S, Iacovino M, Morrison CA, Mountoufaris G, Closser M, Whyte WA, Young RA, Kyba M, Gifford DK, Wichterle H (2011) Embryonic stem cell-based mapping of developmental transcriptional programs. Nat Meth 8(12): $1056-1058$

71. Bird A (2002) DNA methylation patterns and epigenetic memory. Genes Dev 16(1):6-21

72. Hon GC, Rajagopal N, Shen Y, McCleary DF, Yue F, Dang MD, Ren B (2013) Epigenetic memory at embryonic enhancers identified in DNA methylation maps from adult mouse tissues. Nat Genet 45(10):1198-1206

73. Illingworth RS, Gruenewald-Schneider U, Webb S, Kerr AR, James KD, Turner DJ, Smith C, Harrison DJ, Andrews R, Bird AP (2010) Orphan CpG islands identify numerous conserved promoters in the mammalian genome. PLoS Genet 6(9): e1001134

74. Deaton AM, Bird A (2011) CpG islands and the regulation of transcription. Genes Dev 25(10):1010-1022

75. Bestor TH (2000) The DNA methyltransferases of mammals. Hum Mol Genet 9(16):2395-2402

76. Okano M, Bell DW, Haber DA, Li E (1999) DNA methyltransferases Dnmt3a and Dnmt3b are essential for de novo methylation and mammalian development. Cell 99(3):247-257

77. Li E, Bestor TH, Jaenisch R (1992) Targeted mutation of the DNA methyltransferase gene results in embryonic lethality. Cell 69(6):915-926

78. Panning B, Jaenisch R (1996) DNA hypomethylation can activate Xist expression and silence X-linked genes. Genes Dev 10(16): 1991-2002

79. Biniszkiewicz D, Gribnau J, Ramsahoye B, Gaudet F, Eggan K, Humpherys D, Mastrangelo MA, Jun Z, Walter J, Jaenisch R (2002) Dnmt1 overexpression causes genomic hypermethylation, loss of imprinting, and embryonic lethality. Mol Cell Biol 22(7):2124-2135

80. Pannell D, Osborne CS, Yao S, Sukonnik T, Pasceri P, Karaiskakis A, Okano M, Li E, Lipshitz HD, Ellis J (2000) Retrovirus vector silencing is de novo methylase independent and marked by a repressive histone code. EMBO J 19(21): 5884-5894

81. Blattler A, Farnham PJ (2013) Crosstalk between site-specific transcription factors and DNA methylation states. J Biol Chem 288(48):34287-34294

82. Ben-Shushan E, Pikarsky E, Klar A, Bergman Y (1993) Extinction of Oct-3/4 gene expression in embryonal carcinoma $\mathrm{x}$ fibroblast somatic cell hybrids is accompanied by changes in the methylation status, chromatin structure, and transcriptional activity of the Oct-3/ 4 upstream region. Mol Cell Biol 13(2):891-901

83. Tsuji-Takayama K, Inoue T, Ijiri Y, Otani T, Motoda R, Nakamura S, Orita K (2004) Demethylating agent, 5-azacytidine, reverses differentiation of embryonic stem cells. Biochem Biophys Res Commun 323(1):86-90

84. Zhang Y, Ng H-H, Erdjument-Bromage H, Tempst P, Bird A, Reinberg D (1999) Analysis of the NuRD subunits reveals a histone deacetylase core complex and a connection with DNA methylation. Genes Dev 13(15):1924-1935

85. Zhang Y, LeRoy G, Seelig HP, Lane WS, Reinberg D (1998) The dermatomyositis-specific autoantigen Mi2 is a component of a complex containing histone deacetylase and nucleosome remodeling activities. Cell 95(2):279-289

86. Tong JK, Hassig CA, Schnitzler GR, Kingston RE, Schreiber SL (1998) Chromatin deacetylation by an ATP-dependent nucleosome remodelling complex. Nature 395(6705):917-921

87. Xue Y, Wong J, Moreno GT, Young MK, Côté J, Wang W (1998) NURD, a novel complex with both ATP-dependent chromatin-remodeling and histone deacetylase activities. Mol Cell 2(6):851-861 
88. Tahiliani M, Koh KP, Shen Y, Pastor WA, Bandukwala H, Brudno Y, Agarwal S, Iyer LM, Liu DR, Aravind L, Rao A (2009) Conversion of 5-methylcytosine to 5-hydroxymethylcytosine in mammalian DNA by MLL partner TET1. Science 324(5929):930-935

89. Ito S, Shen L, Dai Q, Wu SC, Collins LB, Swenberg JA, He C, Zhang Y (2011) Tet proteins can convert 5-methylcytosine to 5-formylcytosine and 5-carboxylcytosine. Science 333(6047):1300-1303

90. Ito S, D'Alessio AC, Taranova OV, Hong K, Sowers LC, Zhang $\mathrm{Y}$ (2010) Role of Tet proteins in $5 \mathrm{mC}$ to $5 \mathrm{hmC}$ conversion, EScell self-renewal and inner cell mass specification. Nature 466(7310):1129-1133

91. Gao Y, Chen J, Li K, Wu T, Huang B, Liu W, Kou X, Zhang Y, Huang H, Jiang Y, Yao C, Liu X, Lu Z, Xu Z, Kang L, Chen J, Wang H, Cai T, Gao S (2013) Replacement of Oct4 by Tet1 during iPSC induction reveals an important role of DNA methylation and hydroxymethylation in reprogramming. Cell Stem Cell 12(4):453-469

92. Xu Y, Wu F, Tan L, Kong L, Xiong L, Deng J, Barbera AJ, Zheng L, Zhang H, Huang S, Min J, Nicholson T, Chen T, Xu G, Shi Y, Zhang K, Shi YG (2011) Genome-wide regulation of $5 \mathrm{hmC}, 5 \mathrm{mC}$, and gene expression by Tet 1 hydroxylase in mouse embryonic stem cells. Mol Cell 42(4):451-464

93. Pastor WA, Pape UJ, Huang Y, Henderson HR, Lister R, Ko M, McLoughlin EM, Brudno Y, Mahapatra S, Kapranov P, Tahiliani M, Daley GQ, Liu XS, Ecker JR, Milos PM, Agarwal S, Rao A (2011) Genome-wide mapping of 5-hydroxymethylcytosine in embryonic stem cells. Nature 473(7347):394-397

94. Dawlaty MM, Ganz K, Powell BE, Hu YC, Markoulaki S, Cheng AW, Gao Q, Kim J, Choi SW, Page DC, Jaenisch R (2011) Tet1 is dispensable for maintaining pluripotency and its loss is compatible with embryonic and postnatal development. Cell Stem Cell 9(2):166-175

95. Dawlaty MM, Breiling A, Le T, Raddatz G, Barrasa MI, Cheng AW, Gao Q, Powell BE, Li Z, Xu M, Faull KF, Lyko F, Jaenisch R (2013) Combined deficiency of Tet 1 and Tet 2 causes epigenetic abnormalities but is compatible with postnatal development. Dev Cell 24(3):310-323

96. Strahl BD, Allis CD (2000) The language of covalent histone modifications. Nature 403(6765):41-45

97. Efroni S, Duttagupta R, Cheng J, Dehghani H, Hoeppner DJ, Dash C, Bazett-Jones DP, Le Grice S, McKay RD, Buetow KH, Gingeras TR, Misteli T, Meshorer E (2008) Global transcription in pluripotent embryonic stem cells. Cell Stem Cell 2(5): 437-447

98. Krejci J, Uhlirova R, Galiova G, Kozubek S, Smigova J, Bartova E (2009) Genome-wide reduction in H3K9 acetylation during human embryonic stem cell differentiation. J Cell Physiol 219(3):677-687

99. Guenther MG, Levine SS, Boyer LA, Jaenisch R, Young RA (2007) A chromatin landmark and transcription initiation at most promoters in human cells. Cell 130(1):77-88

100. Bernstein BE, Mikkelsen TS, Xie X, Kamal M, Huebert DJ, Cuff J, Fry B, Meissner A, Wernig M, Plath K, Jaenisch R, Wagschal A, Feil R, Schreiber SL, Lander ES (2006) A bivalent chromatin structure marks key developmental genes in embryonic stem cells. Cell 125(2):315-326

101. Pan G, Tian S, Nie J, Yang C, Ruotti V, Wei H, Jonsdottir GA, Stewart R, Thomson JA (2007) Whole-genome analysis of histone H3 lysine 4 and lysine 27 methylation in human embryonic stem cells. Cell Stem Cell 1(3):299-312

102. Zhao XD, Han X, Chew JL, Liu J, Chiu KP, Choo A, Orlov YL, Sung W-K, Shahab A, Kuznetsov VA, Bourque G, Oh S, Ruan Y, Ng H-H, Wei C-L (2007) Whole-genome mapping of histone H3 lys4 and 27 trimethylations reveals distinct genomic compartments in human embryonic stem cells. Cell Stem Cell 1(3):286-298

103. Schuettengruber B, Chourrout D, Vervoort M, Leblanc B, Cavalli G (2007) Genome regulation by Polycomb and Trithorax proteins. Cell 128(4):735-745

104. Schuettengruber B, Martinez A-M, Iovino N, Cavalli G (2011) Trithorax group proteins: switching genes on and keeping them active. Nat Rev Mol Cell Biol 12(12):799-814

105. Lee TI, Jenner RG, Boyer LA, Guenther MG, Levine SS, Kumar RM, Chevalier B, Johnstone SE, Cole MF, Isono K, Koseki H, Fuchikami T, Abe K, Murray HL, Zucker JP, Yuan B, Bell GW, Herbolsheimer E, Hannett NM, Sun K, Odom DT, Otte AP, Volkert TL, Bartel DP, Melton DA, Gifford DK, Jaenisch R, Young RA (2006) Control of developmental regulators by Polycomb in human embryonic stem cells. Cell 125(2):301-313

106. Farcas AM, Blackledge NP, Sudbery I, Long HK, McGouran JF, Rose NR, Lee S, Sims D, Cerase A, Sheahan TW, Koseki H, Brockdorff N, Ponting CP, Kessler BM, Klose RJ, Struhl K (2012) KDM2B links the polycomb repressive complex 1 (PRC1) to recognition of $\mathrm{CpG}$ islands. eLife 1:e00205

107. Wu X, Johansen Jens V, Helin K (2013) Fbx110/Kdm2b recruits polycomb repressive complex 1 to $\mathrm{CpG}$ islands and regulates H2A ubiquitylation. Mol Cell 49(6):1134-1146

108. Blackledge NP, Farcas AM, Kondo T, King HW, McGouran JF, Hanssen LL, Ito S, Cooper S, Kondo K, Koseki Y, Ishikura T, Long HK, Sheahan TW, Brockdorff N, Kessler BM, Koseki H, Klose RJ (2014) Variant PRC1 complex-dependent H2A ubiquitylation drives PRC2 recruitment and polycomb domain formation. Cell 157(6):1445-1459

109. Chamberlain SJ, Yee D, Magnuson T (2008) Polycomb repressive complex 2 is dispensable for maintenance of embryonic stem cell pluripotency. Stem Cells 26(6):1496-1505

110. Shen X, Liu Y, Hsu YJ, Fujiwara Y, Kim J, Mao X, Yuan GC, Orkin SH (2008) EZH1 mediates methylation on histone H3 lysine 27 and complements EZH2 in maintaining stem cell identity and executing pluripotency. Mol Cell 32(4):491-502

111. Landeira D, Sauer S, Poot R, Dvorkina M, Mazzarella L, Jorgensen HF, Pereira CF, Leleu M, Piccolo FM, Spivakov M, Brookes E, Pombo A, Fisher C, Skarnes WC, Snoek T, Bezstarosti K, Demmers J, Klose RJ, Casanova M, Tavares L, Brockdorff N, Merkenschlager M, Fisher AG (2010) Jarid2 is a PRC2 component in embryonic stem cells required for multilineage differentiation and recruitment of PRC1 and RNA polymerase II to developmental regulators. Nat Cell Biol 12(6):618-624

112. Shilatifard A (2012) The COMPASS family of histone H3K4 methylases: mechanisms of regulation in development and disease pathogenesis. Annu Rev Biochem 81(1):65-95

113. Ang YS, Tsai SY, Lee DF, Monk J, Su J, Ratnakumar K, Ding J, Ge Y, Darr H, Chang B, Wang J, Rendl M, Bernstein E, Schaniel C, Lemischka IR (2011) Wdr5 mediates self-renewal and reprogramming via the embryonic stem cell core transcriptional network. Cell 145(2):183-197

114. Jiang H, Shukla A, Wang X, Chen WY, Bernstein BE, Roeder RG (2011) Role for Dpy-30 in ES cell-fate specification by regulation of $\mathrm{H} 3 \mathrm{~K} 4$ methylation within bivalent domains. Cell 144(4):513-525

115. Dou Y, Milne TA, Tackett AJ, Smith ER, Fukuda A, Wysocka J, Allis CD, Chait BT, Hess JL, Roeder RG (2005) Physical association and coordinate function of the H3 K4 methyltransferase MLL1 and the H4 K16 acetyltransferase MOF. Cell 121(6):873-885

116. Li X, Li L, Pandey R, Byun JS, Gardner K, Qin Z, Dou Y (2012) The histone acetyltransferase MOF is a key regulator of the embryonic stem cell core transcriptional network. Cell Stem Cell 11(2):163-178 
117. Blackwood EM, Kadonaga JT (1998) Going the distance: a current view of enhancer action. Science 281(5373):60-63

118. Heintzman ND, Hon GC, Hawkins RD, Kheradpour P, Stark A, Harp LF, Ye Z, Lee LK, Stuart RK, Ching CW, Ching KA, Antosiewicz-Bourget JE, Liu H, Zhang X, Green RD, Lobanenkov VV, Stewart R, Thomson JA, Crawford GE, Kellis M, Ren B (2009) Histone modifications at human enhancers reflect global cell-type-specific gene expression. Nature 459(7243): $108-112$

119. Creyghton MP, Cheng AW, Welstead GG, Kooistra T, Carey BW, Steine EJ, Hanna J, Lodato MA, Frampton GM, Sharp PA, Boyer LA, Young RA, Jaenisch R (2010) Histone H3K27ac separates active from poised enhancers and predicts developmental state. Proc Natl Acad Sci USA 107(50):21931-21936

120. Thurman RE, Rynes E, Humbert R, Vierstra J, Maurano MT, Haugen E, Sheffield NC, Stergachis AB, Wang H, Vernot B, Garg K, John S, Sandstrom R, Bates D, Boatman L, Canfield TK, Diegel M, Dunn D, Ebersol AK, Frum T, Giste E, Johnson AK, Johnson EM, Kutyavin T, Lajoie B, Lee B-K, Lee K, London D, Lotakis D, Neph S, Neri F, Nguyen ED, Qu H, Reynolds AP, Roach V, Safi A, Sanchez ME, Sanyal A, Shafer A, Simon JM, Song L, Vong S, Weaver M, Yan Y, Zhang Z, Zhang Z, Lenhard B, Tewari M, Dorschner MO, Hansen RS, Navas PA, Stamatoyannopoulos G, Iyer VR, Lieb JD, Sunyaev SR, Akey JM, Sabo PJ, Kaul R, Furey TS, Dekker J, Crawford GE, Stamatoyannopoulos JA (2012) The accessible chromatin landscape of the human genome. Nature 489(7414):75-82

121. Rada-Iglesias A, Bajpai R, Swigut T, Brugmann SA, Flynn RA, Wysocka J (2011) A unique chromatin signature uncovers early developmental enhancers in humans. Nature 470(7333):279-283

122. Rada-Iglesias A, Bajpai R, Prescott S, Brugmann SA, Swigut T, Wysocka J (2012) Epigenomic annotation of enhancers predicts transcriptional regulators of human neural crest. Cell Stem Cell 11(5):633-648

123. Shi Y, Lan F, Matson C, Mulligan P, Whetstine JR, Cole PA, Casero RA, Shi Y (2004) Histone demethylation mediated by the nuclear amine oxidase homolog LSD1. Cell 119(7):941-953

124. Whyte WA, Bilodeau S, Orlando DA, Hoke HA, Frampton GM, Foster CT, Cowley SM, Young RA (2012) Enhancer decommissioning by LSD1 during embryonic stem cell differentiation. Nature 482(7384):221-225

125. Kaji K, Caballero IM, MacLeod R, Nichols J, Wilson VA, Hendrich B (2006) The NuRD component Mbd3 is required for pluripotency of embryonic stem cells. Nat Cell Biol 8(3): 285-292

126. Wang Z, Zang C, Cui K, Schones DE, Barski A, Peng W, Zhao $\mathrm{K}$ (2009) Genome-wide mapping of HATs and HDACs reveals distinct functions in active and inactive genes. Cell 138(5): 1019-1031

127. Ho L, Ronan JL, Wu J, Staahl BT, Chen L, Kuo A, Lessard J, Nesvizhskii AI, Ranish J, Crabtree GR (2009) An embryonic stem cell chromatin remodeling complex, esBAF, is essential for embryonic stem cell self-renewal and pluripotency. Proc Natl Acad Sci USA 106(13):5181-5186

128. Ho L, Jothi R, Ronan JL, Cui K, Zhao K, Crabtree GR (2009) An embryonic stem cell chromatin remodeling complex, esBAF, is an essential component of the core pluripotency transcriptional network. Proc Natl Acad Sci USA 106(13):5187-5191

129. Gao X, Tate P, Hu P, Tjian R, Skarnes WC, Wang Z (2008) ES cell pluripotency and germ-layer formation require the SWI/ SNF chromatin remodeling component BAF250a. Proc Natl Acad Sci USA 105(18):6656-6661

130. Fazzio TG, Huff JT, Panning B (2008) An RNAi screen of chromatin proteins identifies Tip60-p400 as a regulator of embryonic stem cell identity. Cell 134(1):162-174
131. Gevry N, Chan HM, Laflamme L, Livingston DM, Gaudreau L (2007) p21 transcription is regulated by differential localization of histone H2A.Z. Genes Dev 21(15):1869-1881

132. Wang L, Du Y, Ward James M, Shimbo T, Lackford B, Zheng X, Miao Y-1, Zhou B, Han L, Fargo David C, Jothi R, Williams Carmen J, Wade Paul A, Hu G (2014) INO80 facilitates pluripotency gene activation in embryonic stem cell self-renewal, reprogramming, and blastocyst development. Cell Stem Cell 14(5):575-591

133. Wu JI (2012) Diverse functions of ATP-dependent chromatin remodeling complexes in development and cancer. Acta Biochim Biophys Sin (Shanghai) 44(1):54-69

134. Stopka T, Skoultchi AI (2003) The ISWI ATPase Snf2h is required for early mouse development. Proc Natl Acad Sci USA 100(24):14097-14102

135. Wysocka J, Swigut T, Xiao H, Milne TA, Kwon SY, Landry J, Kauer M, Tackett AJ, Chait BT, Badenhorst P, Wu C, Allis CD (2006) A PHD finger of NURF couples histone H3 lysine 4 trimethylation with chromatin remodelling. Nature 442(7098): 86-90

136. Landry J, Sharov AA, Piao Y, Sharova LV, Xiao H, Southon E, Matta J, Tessarollo L, Zhang YE, Ko MS, Kuehn MR, Yamaguchi TP, Wu C (2008) Essential role of chromatin remodeling protein Bptf in early mouse embryos and embryonic stem cells. PLoS Genet 4(10):e1000241

137. Sims RJ 3rd, Chen CF, Santos-Rosa H, Kouzarides T, Patel SS, Reinberg D (2005) Human but not yeast CHD1 binds directly and selectively to histone $\mathrm{H} 3$ methylated at lysine 4 via its tandem chromodomains. J Biol Chem 280(51):41789-41792

138. Heintzman ND, Stuart RK, Hon G, Fu Y, Ching CW, Hawkins RD, Barrera LO, Van Calcar S, Qu C, Ching KA, Wang W, Weng Z, Green RD, Crawford GE, Ren B (2007) Distinct and predictive chromatin signatures of transcriptional promoters and enhancers in the human genome. Nat Genet 39(3):311-318

139. Gaspar-Maia A, Alajem A, Polesso F, Sridharan R, Mason MJ, Heidersbach A, Ramalho-Santos J, McManus MT, Plath K, Meshorer E, Ramalho-Santos M (2009) Chd1 regulates open chromatin and pluripotency of embryonic stem cells. Nature 460(7257):863-868

140. Bosman EA, Penn AC, Ambrose JC, Kettleborough R, Stemple DL, Steel KP (2005) Multiple mutations in mouse Chd7 provide models for CHARGE syndrome. Hum Mol Genet 14(22): 3463-3476

141. Schnetz MP, Bartels CF, Shastri K, Balasubramanian D, Zentner GE, Balaji R, Zhang X, Song L, Wang Z, Laframboise T, Crawford GE, Scacheri PC (2009) Genomic distribution of CHD7 on chromatin tracks H3K4 methylation patterns. Genome Res 19(4):590-601

142. Cremer T, Cremer C (2006) Rise, fall and resurrection of chromosome territories: a historical perspective. Part II. Fall and resurrection of chromosome territories during the 1950s to 1980s. Part III. Chromosome territories and the functional nuclear architecture: experiments and models from the 1990s to the present. Eur J Histochem 50(4):223-272

143. Mattout A, Meshorer E (2010) Chromatin plasticity and genome organization in pluripotent embryonic stem cells. Curr Opin Cell Biol 22(3):334-341

144. Meshorer E, Misteli T (2006) Chromatin in pluripotent embryonic stem cells and differentiation. Nat Rev Mol Cell Biol 7(7):540-546

145. Misteli T (2007) Beyond the sequence: cellular organization of genome function. Cell 128(4):787-800

146. Bartova E, Kozubek S (2006) Nuclear architecture in the light of gene expression and cell differentiation studies. Biol Cell 98(6):323-336 
147. Lieberman-Aiden E, van Berkum NL, Williams L, Imakaev M, Ragoczy T, Telling A, Amit I, Lajoie BR, Sabo PJ, Dorschner MO, Sandstrom R, Bernstein B, Bender MA, Groudine M, Gnirke A, Stamatoyannopoulos J, Mirny LA, Lander ES, Dekker J (2009) Comprehensive mapping of long-range interactions reveals folding principles of the human genome. Science 326(5950):289-293

148. Dixon JR, Selvaraj S, Yue F, Kim A, Li Y, Shen Y, Hu M, Liu JS, Ren B (2012) Topological domains in mammalian genomes identified by analysis of chromatin interactions. Nature 485(7398):376-380

149. Croft JA, Bridger JM, Boyle S, Perry P, Teague P, Bickmore WA (1999) Differences in the localization and morphology of chromosomes in the human nucleus. J Cell Biol 145(6):1119-1131

150. Carvalho C, Pereira HM, Ferreira J, Pina C, Mendonça D, Rosa AC, Carmo-Fonseca M (2001) Chromosomal G-dark bands determine the spatial organization of centromeric heterochromatin in the nucleus. Mol Biol Cell 12(11):3563-3572

151. Wiblin AE, Cui W, Clark AJ, Bickmore WA (2005) Distinctive nuclear organisation of centromeres and regions involved in pluripotency in human embryonic stem cells. J Cell Sci 118(Pt 17):3861-3968

152. Peric-Hupkes D, Meuleman W, Pagie L, Bruggeman SW, Solovei I, Brugman W, Graf S, Flicek P, Kerkhoven RM, van Lohuizen M, Reinders M, Wessels L, van Steensel B (2010) Molecular maps of the reorganization of genome-nuclear lamina interactions during differentiation. Mol Cell 38(4):603-613

153. Chambeyron S, Bickmore WA (2004) Chromatin decondensation and nuclear reorganization of the HoxB locus upon induction of transcription. Genes Dev 18(10):1119-1130

154. Dekker J, Rippe K, Dekker M, Kleckner N (2002) Capturing chromosome conformation. Science 295(5558):1306-1311

155. de Wit E, de Laat W (2012) A decade of 3C technologies: insights into nuclear organization. Genes Dev 26(1):11-24

156. Simonis M, Klous P, Splinter E, Moshkin Y, Willemsen R, de Wit E, van Steensel B, de Laat W (2006) Nuclear organization of active and inactive chromatin domains uncovered by chromosome conformation capture-on-chip (4C). Nat Genet 38(11):1348-1354

157. Splinter E, de Wit E, Nora EP, Klous P, van de Werken HJ, Zhu Y, Kaaij LJ, van Ijcken W, Gribnau J, Heard E, de Laat W (2011) The inactive $X$ chromosome adopts a unique threedimensional conformation that is dependent on Xist RNA. Genes Dev 25(13):1371-1383

158. Dostie J, Richmond TA, Arnaout RA, Selzer RR, Lee WL, Honan TA, Rubio ED, Krumm A, Lamb J, Nusbaum C, Green RD, Dekker J (2006) Chromosome Conformation Capture Carbon Copy (5C): a massively parallel solution for mapping interactions between genomic elements. Genome Res 16(10):1299-1309

159. Wang JC, Giaever GN (1988) Action at a distance along a DNA. Science 240(4850):300-304

160. Handoko L, Xu H, Li G, Ngan CY, Chew E, Schnapp M, Lee $\mathrm{CW}$, Ye C, Ping JL, Mulawadi F, Wong E, Sheng J, Zhang Y, Poh T, Chan CS, Kunarso G, Shahab A, Bourque G, CacheuxRataboul V, Sung WK, Ruan Y, Wei CL (2011) CTCF-mediated functional chromatin interactome in pluripotent cells. Nat Genet 43(7):630-638

161. Botta M, Haider S, Leung IX, Lio P, Mozziconacci J (2010) Intra- and inter-chromosomal interactions correlate with CTCF binding genome wide. Mol Syst Biol 6:426

162. Cuddapah S, Jothi R, Schones DE, Roh T-Y, Cui K, Zhao K (2009) Global analysis of the insulator binding protein CTCF in chromatin barrier regions reveals demarcation of active and repressive domains. Genome Res 19(1):24-32
163. Fang F, Xu Y, Chew KK, Chen X, Ng HH, Matsudaira P (2014) Coactivators p300 and CBP maintain the identity of mouse embryonic stem cells by mediating long-range chromatin structure. Stem Cells 32(7):1805-1816

164. Borggrefe T, Yue X (2011) Interactions between subunits of the mediator complex with gene-specific transcription factors. Semin Cell Dev Biol 22(7):759-768

165. Soutourina J, Wydau S, Ambroise Y, Boschiero C, Werner M (2011) Direct interaction of RNA polymerase II and mediator required for transcription in vivo. Science 331(6023):1451-1454

166. Zhang Y, Wong C-H, Birnbaum RY, Li G, Favaro R, Ngan CY, Lim J, Tai E, Poh HM, Wong E, Mulawadi FH, Sung W-K, Nicolis S, Ahituv N, Ruan Y, Wei C-L (2013) Chromatin connectivity maps reveal dynamic promoter-enhancer long-range associations. Nature 504(7479):306-310

167. Kieffer-Kwon KR, Tang Z, Mathe E, Qian J, Sung MH, Li G, Resch W, Baek S, Pruett N, Grontved L, Vian L, Nelson S, Zare H, Hakim O, Reyon D, Yamane A, Nakahashi H, Kovalchuk AL, Zou J, Joung JK, Sartorelli V, Wei CL, Ruan X, Hager GL, Ruan Y, Casellas R (2013) Interactome maps of mouse gene regulatory domains reveal basic principles of transcriptional regulation. Cell 155(7):1507-1520

168. Wei Z, Gao F, Kim S, Yang H, Lyu J, An W, Wang K, Lu W (2013) Klf4 organizes long-range chromosomal interactions with the oct 4 locus in reprogramming and pluripotency. Cell Stem Cell 13(1):36-47

169. Apostolou E, Ferrari F, Walsh RM, Bar-Nur O, Stadtfeld M, Cheloufi S, Stuart HT, Polo JM, Ohsumi TK, Borowsky ML, Kharchenko PV, Park PJ, Hochedlinger K (2013) Genome-wide chromatin interactions of the Nanog locus in pluripotency, differentiation, and reprogramming. Cell Stem Cell 12(6):699-712

170. Denholtz M, Bonora G, Chronis C, Splinter E, de Laat W, Ernst J, Pellegrini M, Plath K (2013) Long-range chromatin contacts in embryonic stem cells reveal a role for pluripotency factors and polycomb proteins in genome organization. Cell Stem Cell 13(5):602-616

171. Cheutin T, Cavalli G (2012) Progressive Polycomb assembly on H3K27me3 compartments generates Polycomb Bodies with developmentally regulated motion. PLoS Genet 8(1):e1002465

172. Struhl K (1998) Histone acetylation and transcriptional regulatory mechanisms. Genes Dev 12(5):599-606

173. McMahon S, Wood M, Cole M (2000) The essential cofactor TRRAP recruits the histone acetyltransferase hGCN5 to c-Myc. Mol Cell Biol 20:556-562

174. Teif VB, Vainshtein Y, Caudron-Herger M, Mallm J-P, Marth C, Höfer T, Rippe K (2012) Genome-wide nucleosome positioning during embryonic stem cell development. Nat Struct Mol Biol 19(11):1185-1192

175. Schnetz MP, Handoko L, Akhtar-Zaidi B, Bartels CF, Pereira CF, Fisher AG, Adams DJ, Flicek P, Crawford GE, LaFramboise T, Tesar P, Wei C-L, Scacheri PC (2010) CHD7 targets active gene enhancer elements to modulate ES cell-specific gene expression. PLoS Genet 6(7):e1001023

176. Zaret KS, Carroll JS (2011) Pioneer transcription factors: establishing competence for gene expression. Genes Dev 25(21):2227-2241

177. Cole MF, Johnstone SE, Newman JJ, Kagey MH, Young RA (2008) Tcf3 is an integral component of the core regulatory circuitry of embryonic stem cells. Genes Dev 22(6):746-755

178. Magnani L, Eeckhoute J, Lupien M (2011) Pioneer factors: directing transcriptional regulators within the chromatin environment. Trends Genet 27(11):465-474

179. Cirillo LA, Lin FR, Cuesta I, Friedman D, Jarnik M, Zaret KS (2002) Opening of compacted chromatin by early developmental transcription factors HNF3 (FoxA) and GATA-4. Mol Cell 9(2):279-289 
180. Soufi A, Donahue G, Zaret Kenneth S (2012) Facilitators and impediments of the pluripotency reprogramming factors' initial engagement with the genome. Cell 151(5):994-1004

181. Cirillo LA, Zaret KS (1999) An early developmental transcription factor complex that is more stable on nucleosome core particles than on free DNA. Mol Cell 4(6):961-969

182. Mutoh H, Fukuda T, Kitamaoto T, Masushige S, Sasaki H, Shimizu T, Kato S (1996) Tissue-specific response of the human platelet-activating factor receptor gene to retinoic acid and thyroid hormone by alternative promoter usage. Proc Natl Acad Sci USA 93(2):774-779

183. Roel G, Hamilton FS, Gent Y, Bain AA, Destree O, Hoppler S (2002) Lef-1 and Tcf-3 transcription factors mediate tissuespecific Wnt signaling during Xenopus development. Curr Biol 12(22):1941-1945

184. Kiel C, Yus E, Serrano L (2010) Engineering signal transduction pathways. Cell 140(1):33-47

185. Schoenfelder S, Sexton T, Chakalova L, Cope NF, Horton A, Andrews S, Kurukuti S, Mitchell JA, Umlauf D, Dimitrova DS, Eskiw CH, Luo Y, Wei C-L, Ruan Y, Bieker JJ, Fraser P (2010) Preferential associations between co-regulated genes reveal a transcriptional interactome in erythroid cells. Nat Genet 42(1):53-61
186. Wang J, Scully K, Zhu X, Cai L, Zhang J, Prefontaine GG, Krones A, Ohgi KA, Zhu P, Garcia-Bassets I, Liu F, Taylor H, Lozach J, Jayes FL, Korach KS, Glass CK, Fu X-D, Rosenfeld MG (2007) Opposing LSD1 complexes function in developmental gene activation and repression programmes. Nature 446(7138):882-887

187. Farnham PJ (2009) Insights from genomic profiling of transcription factors. Nat Rev Genet 10(9):605-616

188. Scacheri PC, Davis S, Odom DT, Crawford GE, Perkins S, Halawi MJ, Agarwal SK, Marx SJ, Spiegel AM, Meltzer PS, Collins FS (2006) Genome-wide analysis of menin binding provides insights into MEN1 tumorigenesis. PLoS Genet 2(4):e51

189. Le Phuc P, Friedman JR, Schug J, Brestelli JE, Parker JB, Bochkis IM, Kaestner KH (2005) Glucocorticoid receptordependent gene regulatory networks. PLoS Genet 1(2):e16

190. Cheng J, Blum R, Bowman C, Hu D, Shilatifard A, Shen S, Dynlacht Brian D (2014) A role for H3K4 monomethylation in gene repression and partitioning of chromatin readers. Mol Cell 53(6):979-992 